\title{
Relationship between some selected major, minor and trace elements in the IOCG deposits (on the example of the unique Sin Quyen deposit, Lao Cai province, north Vietnam)
}

\author{
H. Duong $\operatorname{Van}^{1}$, C. Nguyen Dinh ${ }^{2 *}$, A. Piestrzynski², J. Pieczonka ${ }^{2}$ \\ ${ }^{1}$ University of Mining and Geology (UMG), Hanoi, Vietnam \\ ${ }^{2}$ AGH University of Science and Technology (AGH-UST), Krakow, Poland \\ cnd@agh.edu.pl
}

\begin{abstract}
In the paper the authors attempted to study the relations between several selected elements present in the IOCG Sin Quyen deposit, Lao Cai, North Vietnam and to interpret the obtained correlations especially with coefficient higher than 0.7. The correlations with high coefficients are mainly observed for the elements belonging to the chalcophile group $(\mathrm{Cu}, \mathrm{Ag}, \mathrm{Au}$, $\mathrm{Te}, \mathrm{Bi}$ ) and for the relation between uranium and $\mathrm{Ag}, \mathrm{Au}, \mathrm{Cu}, \mathrm{Pb}$ and $\mathrm{Bi}$. But the $\mathrm{S}$ and $\mathrm{Fe}$ as well as REE currying minerals are predominant in the studied deposit, but no strong correlation between them and other elements was observed even with $\mathrm{Cu}$. The phenomena primarily explained based on the geochemistry properties of the mentioned elements and the characteristics of IOCG deposits.
\end{abstract}

Keywords: IOCG Sin Quyen deposit, correlations, geochemistry

\section{Introduction}

Generally the IOCG deposits are known as the deposits with the elevated contents of $\mathrm{Cu}, \mathrm{Au}, \mathrm{Ag}, \mathrm{REE}, \mathrm{U}, \mathrm{P}$ and Co. They are controlled structurally or stratigraphically and temporally and spatially associated with presence Na-Ca-K alteration (Barton, 2014). According to numerous scientists the IOCG deposits could be formed as a consequence of processes as: (1) magmatic hydrothermal fluid activity, (2) metamorphic hydrothermal fluids derived from crustal source at depth, and (3) terrestrial hydrothermal fluids circulated by intrusive or crustal heat (Hitzman et al., 1992; Groves et al., 2010). The mineral and chemical composition spectra of the IOCG deposits are very inhomogeneous even within one area (Li et al., 2014). The variety both in mineral composition and in ore distribution within a deposit can be connected with many periods of the magmatism activity and geological forming structures. The inhomogeneous are also reflected in variable ratios of different elements: $\mathrm{Cu} / \mathrm{Au}, \mathrm{Au} / \mathrm{Ag}$ and so on (Ivan et al., 2002; Zhu, 2016). Depending on the local geological conditions, the IOCG deposits can be poor or rich in $\mathrm{Fe}, \mathrm{Cu}$ or other mentioned elements (Requia and Fontbote, 2000; Gandhi, 2003; Requia et al., 2003). Therefore not only Fe or $\mathrm{Cu}$ can be a main mined ores, but also $\mathrm{Au}, \mathrm{Ag}, \mathrm{U}$ or REE are as the valuable commodities.

There is an important role for geochemistry in the exploration workflow. Especially, for very broad distribution of trace elements around IOCG deposits, and these can be used to recognize 'halos' within mineral systems, also for deposits beneath thick surface sediment formation (Fabris et al., 2015).

In geochemistry the stochastic dependences between different major and trace elements occurring in deposit are often analyzed, because the relations could enable us to understand and to explain some unexpected phenomena or emerge some valuable rules. For example in the ores of high Fe grade there is often low Ti with variable $\mathrm{Cu}, \mathrm{Au}, \mathrm{Ag}$ as well as REE or in allanites-Ce the REE concentration is inversely proportional to the Ca contents (Zhao and Zhou, 2011; Barton, 2014). Ag contents in multistage deposits (skarn, massive sulfides, and black shale) abrupt increase in later low-temperature assemblages regardless of deposit type (Gas'kov, 2017). Letnikova with her co-workers (2011) used geochemical correlations of different oxides to reconstruct the geodynamic processes of forming deposits in Tuva-Mongolian Massif. In the placer gold deposits in the East of Siberian Platform with increasing of $\mathrm{Au}$ fineness the $\mathrm{Ag}$ content is decreased and $\mathrm{Cu}$ has an increasing tendency (Nikiforova et al., 2018).

Though the IOCG Sin Quyen deposit has been investigated by several scientists, but they have principally focused on the geological structure, ore crystallization ages and occurrence of the specific minerals (Ta, 1975; 
McLean, 2001; Ishihara et al., 2011; Gas'kov et al., 2012; Li and Zhou, 2018; Pieczonka et al., 2019). The correlation coefficients between some elements in IOCG Sin Quyen deposit were also estimated by Gas'kov et al. (2012), but the correlations were not interpreted or very weakly considered. In this paper we intend to present some interesting characteristic correlations between chalcophile elements $(\mathrm{Cu}, \mathrm{Ag}, \mathrm{Au}, \mathrm{Pb}, \mathrm{Bi}, \mathrm{Te}$, and $\mathrm{Zn}$ ), the siderophile elements ( $\mathrm{Fe}, \mathrm{Co}, \mathrm{Ni})$, the lithophile elements as well as between the radioactive elements (Th, U) and major ore elements $\mathrm{Cu}, \mathrm{Au}, \mathrm{Ag}$ and REE. Though in the IOCG Sin Quyen deposit the sulfur and iron currying minerals are dominating but there is no correlation between these elements and others even with $\mathrm{Cu}$, the phenomena will be also considered.

\section{Study area}

The Sin Quyen IOCG deposit is located in the Lao Cai province, $300 \mathrm{~km}$ north-western from Hanoi and one $\mathrm{km}$ from the Red River, which is the natural boundary with China (Fig.1). The coordinate of the deposit is $22^{\circ}$ $37^{\prime} 20^{\prime \prime}$ of latitude and $103^{\circ} 48^{\prime} 00^{\prime}$ ' of longitude with 200 ha of area. From the geological point of view, the deposit is within the Red River zone in the west of the Fanxipan belt. The Fanxipan belt divides the North Vietnam into the South China block and the Indochina block, and trending in the NW-SE direction with near $300 \mathrm{~km}$ long in the Vietnam territory. The Fanxipan belt is composed of high-grade metamorphic complex zone. The Red River zone is composed of the Suoi Chieng and Sin Quyen formations (Fig.2). The Suoi Chieng formation with near $600 \mathrm{~m}$ thick is built principally from the Proterozoic terrigenous sediments and granitic gneiss, biotite-amphibole gneiss and biotite schits. The Suoi Chieng suit is covered conformably by the Sin Quyen formation with 1200 m round of thick. From the facies point of view the Sin Quyen formation is divided into lower and upper units. In the lower unit there is gneiss composing of the biotite, muscovite and graphite quartz, while the composition of the upper unit is similar to the lower one, but without graphite. The Sin Quyen formation is intruded by several mafic intrusive dikes or lenses and is overlain conformable by the CambroOrdovician Cam Duong sediments (McLean, 2001; Gas'kov et al., 2012; Ishihara et al., 2011).

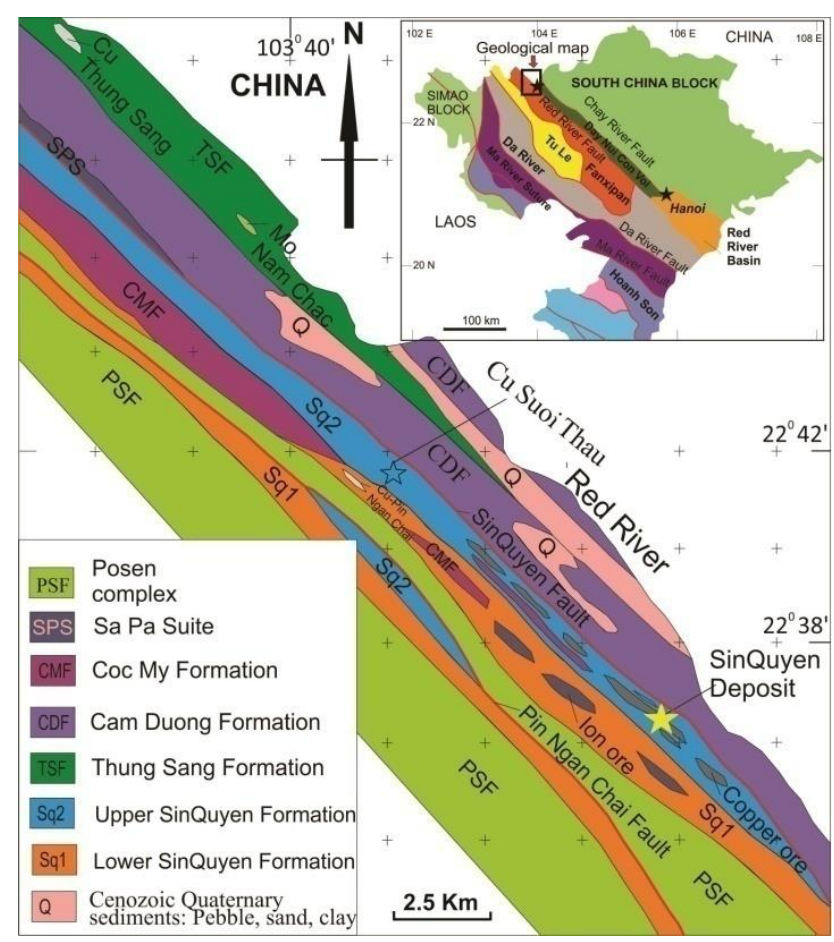

Fig. 1. Localization of the Sin Quyen deposit on the geological sketch of the North Vietnam 


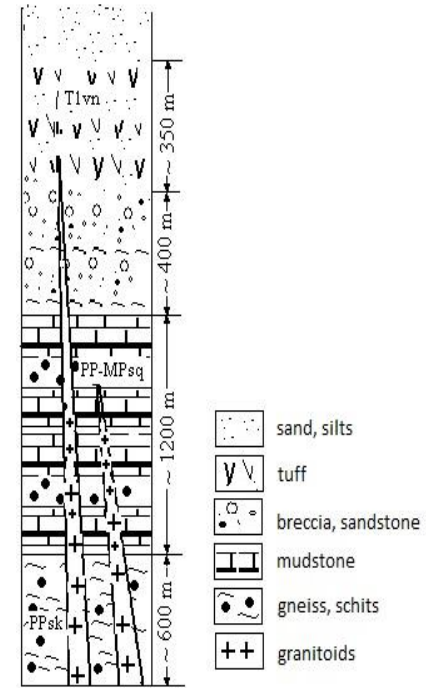

Fig. 2. Schematic illustration of the rock formation in the Sin Quyen region

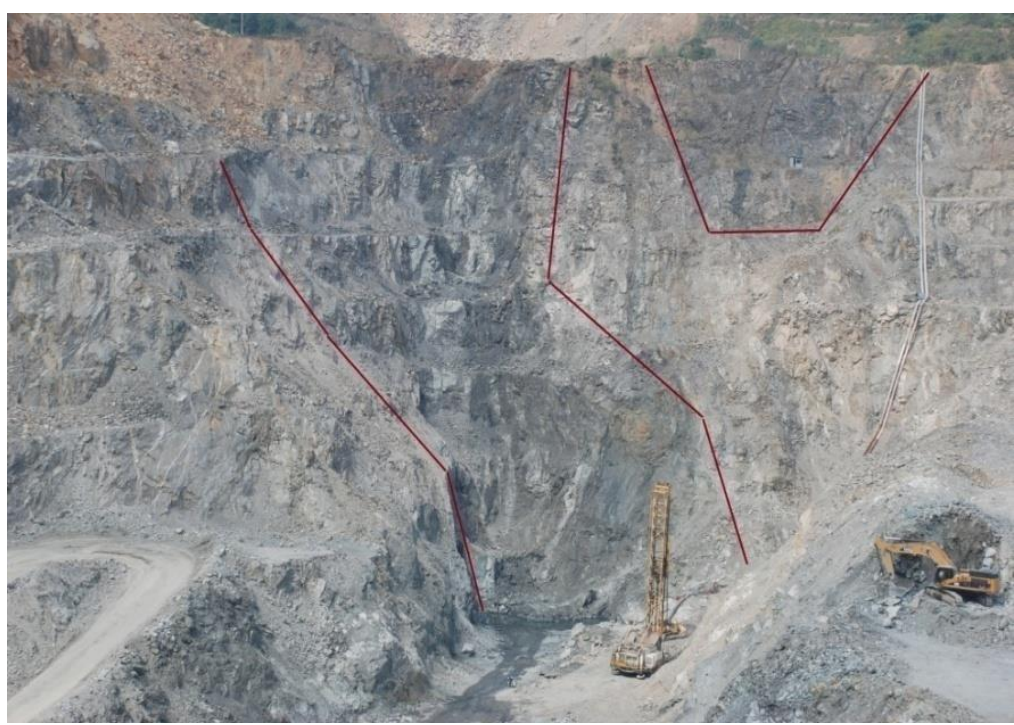

Fig. 3. Cross section of the ore body (photo 2015, looking NW direction)

The ore bodies of the IOCG Sin Quyen deposit principally are hosted in the Sin Quyen formation, they occur as the lenses with several tens meters thick and up to few hundred meters long, trending NW-SE and dipping near vertically $\left(70-90^{\circ}\right.$ ) (Fig. 3). The major ore minerals are Au-, Ag-rich copper and iron sulfides (chalcopyrite, pyrite, and pyrrhotite) and iron oxides (magnetite, hematite). The average grade of $\mathrm{Cu}$, LREE and $\mathrm{Au}$ is equal to 0.9 wt.\%, $0.7 \mathrm{wt} \%$ and $0.44 \mathrm{ppm}$ respectively. With the $\mathrm{Cu}$ grade of 0.9 wt.\% and the maximum depth of the ore body occurrence $350 \mathrm{~m}$ b.s.l, the $\mathrm{Cu}$ calculated resource of the IOCG Sin Quyen deposit amounts to near 90 Mt (McLean, 2001; Pham et al., 2015). The deposit has an uncommon ore composition and divided horizontally into two parts (Fig. 4). The first is wide spread in the central and eastern area, in this part the main ore minerals are chalcopyrite, pyrrhotite and pyrite, the minerals contribute near $90 \%$ ore composition. The second part predominates in the western, where the major minerals are magnetite, pyrite, chalcopyrite and pyrrhotite contributing from a few percent up to 50\% of ore (McLean, 2001; Gas'kov et al., 2012). Due to the occurrence of the large fractures system, the oxidized zone is clearly observed in the upper part near $100 \mathrm{~m}$ of depth below the earth surface (Fig. 5) (Pieczonka et al., 2019).

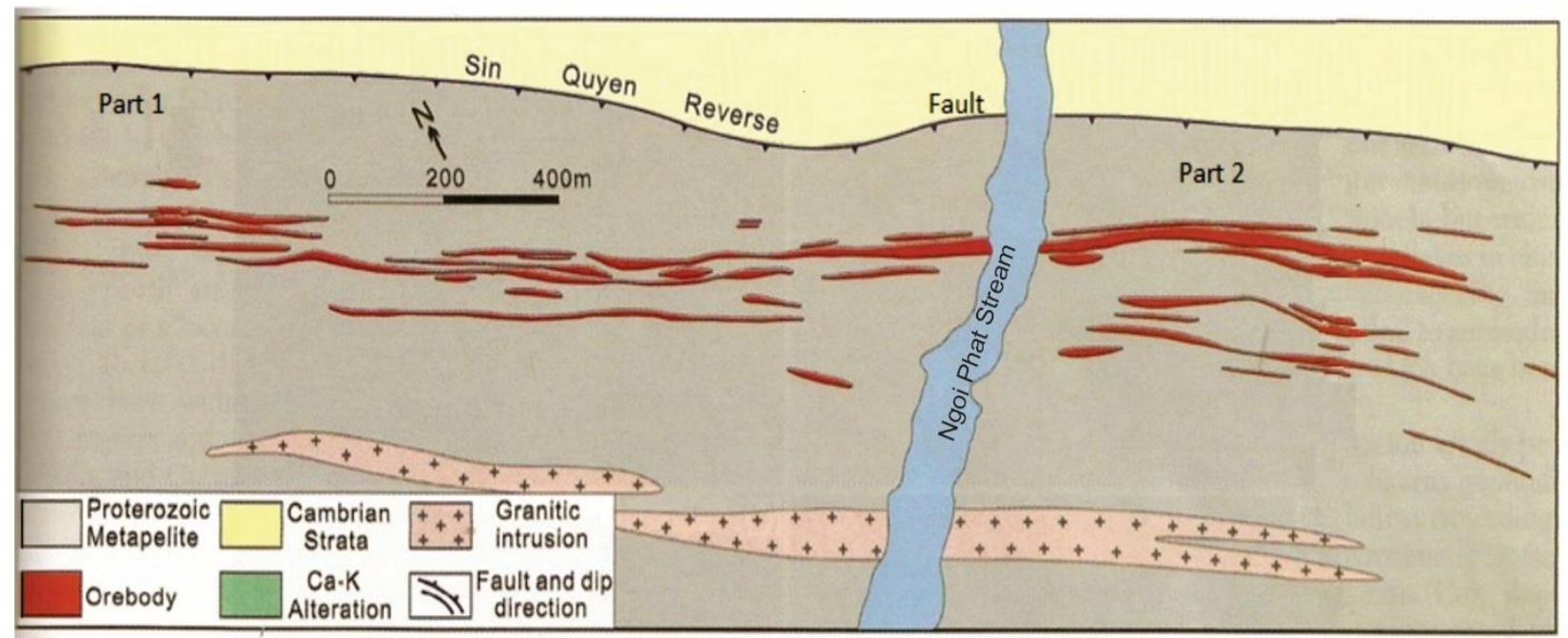

Fig. 4. Modified Geological sketch of Sing Quyen deposit after Ta (1975)

According to Li et al. (2017), in the deposit region there were four principal mineralization stages: (i) the paragenetic sequence including with the sodic alteration, which was happened in the Proterozoic epoch; (ii) the calcic-potassic alteration and associated Fe-REE-(U) mineralization lasted in the Neoproterozoic (841 to 
$836 \mathrm{Ma}$ ); (iii) $\mathrm{Cu}-\mathrm{Au}$ mineralization, the third stage probable happened at $500 \mathrm{Ma}$ (Pieczonka et al., 2015, 2019) and the fourth stage was connected with the metamorphism occurred at the $30 \mathrm{Ma}$ and the sulfide(quartz-carbonate) veins were mostly established. The mineralization of the Sin Quyen deposit basically falls within the age range of the Neoproterozoic igneous rocks (740 - $860 \mathrm{Ma})$ (Li et al., 2017).

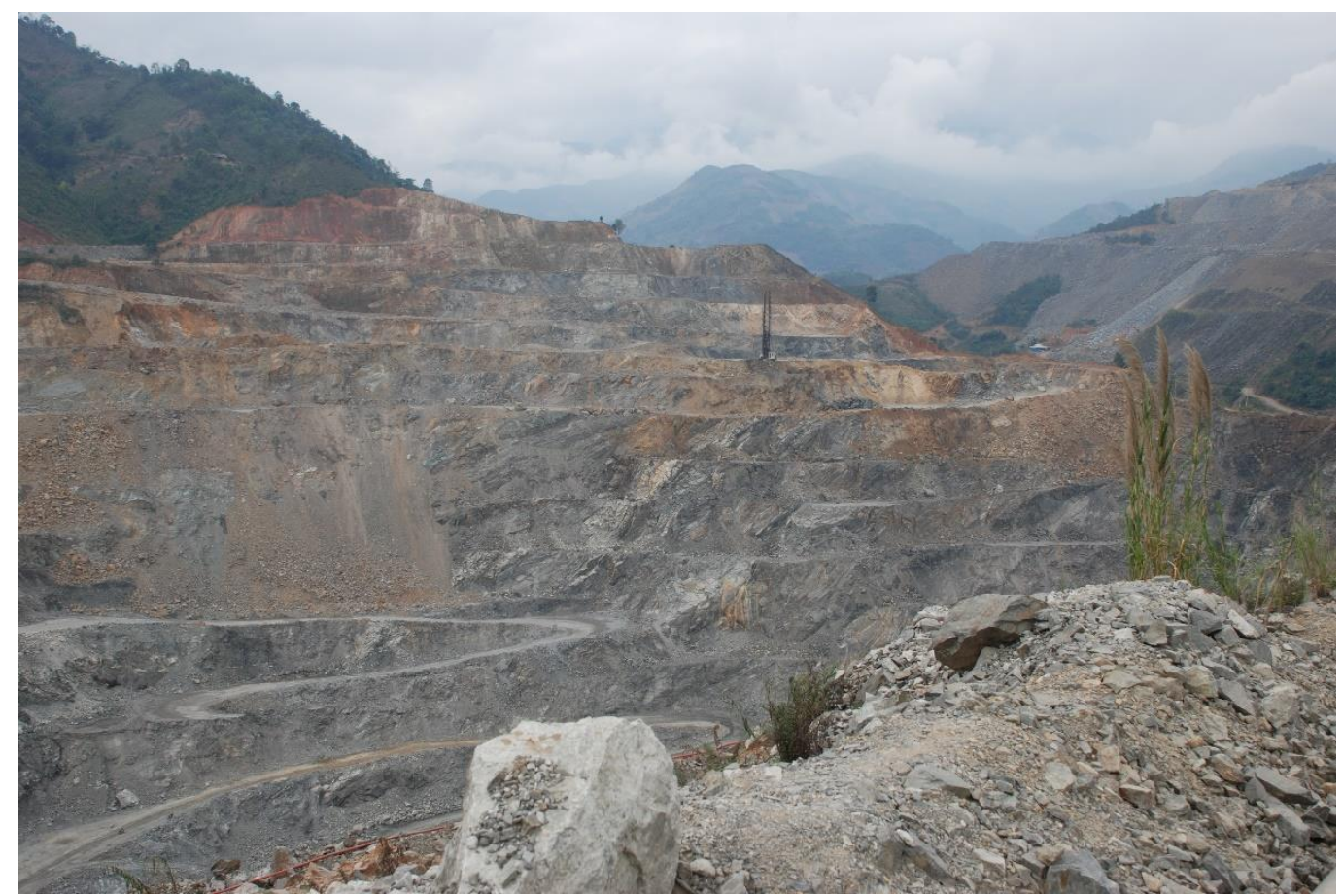

Fig. 5. View of weathered zone (photo, 2014)

\section{Materials and methods}

On November 2014 at the IOCG Sin Quyen deposit, 50 solid samples from massive ores, host rocks, reservoir sediments, $\mathrm{Cu}$ - and Fe-concentrates and from waste dumps were collected. The localization of the sampling places is shown in figure 6 .

All the collected samples were analyzed by optical microscope at AGH University of Science and Technology (AGH UST). Based on the results of the microscope analyze, 39 samples were selected for the chemical compositions and natural radionuclides analyzed. The chemical composition was analyzed at Bureau Veritas Mineral Laboratories in Canada using the method assigned as AQ251 and NAA. The sample of $0.5 \mathrm{~g}$ was digested in Aqua Regia at $90{ }^{\circ} \mathrm{C}$ followed by an ICP-MS. The analytical methods in detailed, detection limits and uncertainties can be downloaded from the ACME Laboratories website at www.acmelab.com. Analytical uncertainties are typically 5\% for most analysed elements. Detection limit for REEs varies from 0.02 up to 0.5 $\mathrm{ppm}$. For the natural radionuclide determination, the sample was milled until the grains became less than 2 $\mathrm{mm}$, then it was dried in an oven at $120^{\circ} \mathrm{C}$ for $24 \mathrm{~h}$ to ensure that moisture was completely removed, then weighted and packed in an aluminum cylindrical beaker and sealed to prevent the escape of radon. The weighed and tightly sealed samples were left for at least 21 days to reach secular equilibrium between ${ }^{226} \mathrm{Ra}$ and ${ }^{222} \mathrm{Rn}$ as well as its daughters (mostly ${ }^{214} \mathrm{Bi}$ and ${ }^{214} \mathrm{~Pb}$ ). The activity concentration was determined using a semiconductor HPGe detector (Canberra GX4020) with 42\% relative efficiency. The energy resolution of the spectrometer at the line $1333 \mathrm{keV}\left({ }^{60} \mathrm{Co}\right)$ is near $2 \mathrm{keV}$. As standard samples, reference materials RG produced by the International Atomic Energy Agency (IAEA) were used. Samples were measured in cylindrical beaker with $48 \mathrm{~cm}^{3}$ of volume (sample diameter $70 \mathrm{~mm}$, height $12.5 \mathrm{~mm}$ ) placed directly on the detector. The measurement time of samples amounted near $50 \mathrm{~h}$. A detail description of the methodology is presented by Jodlowski and Kalita (2010). 


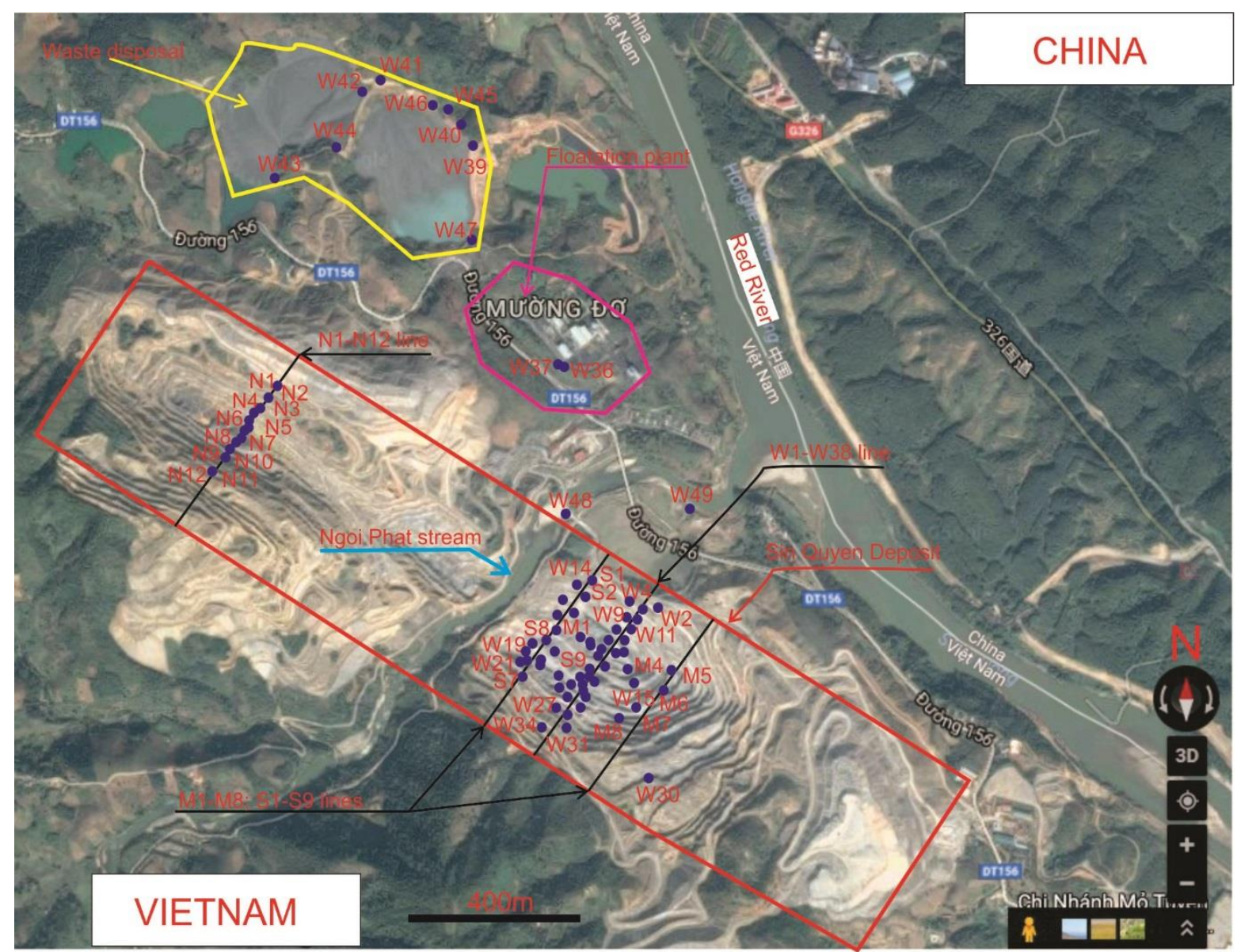

Fig. 6. Sampling localization

\section{Results and discussions}

The analyzed chemical concentration of the most measured elements in the samples varied in the broad ranges (Table 1). The ratio of the maximum to minimum concentrations in the ore samples of the major elements range from $10^{2}$ to $10^{5}(\mathrm{ppm})$. The Fe concentration in the ore ranges from near $1 \%$ to $40 \%$. The maximum concentration of $\mathrm{Fe}$ in the massive ore is on the level of the Fe concentrate (samples W18, W37), Cu content ranges from near $0.004 \%$ up to $11 \%$ (samples W31a and S4), the Au and Ag average concentrations are higher than that of earth crust about $10^{5}$ and $10^{3}$ fold and equal to 1662 and $1163 \mathrm{ppb}$ respectively. Gold and silver are randomly occurring as an electrum mineral in a vein forms (Fig. 7a). The economic or anomalous gold is common characteristic for IOCG deposits in the World (Zhu, 2016). In the deposit REE bearing minerals are allanites occurring in disseminated manner (Fig. 7b). The total concentration of rare earth elements (TREE) varies from $22 \mathrm{ppm}$ to about $2500 \mathrm{ppm}$ with $700 \mathrm{ppm}$ of average. The concentration of light rare earth element (LREE) is significantly higher than that of heavy rare earth elements (HREE), their average ratio (LREE/HREE) equal to 70 . The sulfur grade ranges from 0.06 to $7.5 \%$ with $2.04 \%$ of average. This value is near $10^{3}$ times higher than the earth crust average concentration. The average $U$ and Th concentrations are 84 and $13 \mathrm{ppm}$ and higher than the earth average concentration by 24 and 1.4 fold respectively, so the uranium is the main radioactive element in the deposit. The general reasons for uranium enrichment in IOCG deposit could include the hydrothermal fluids (Hitzman and Valenta, 2005). 


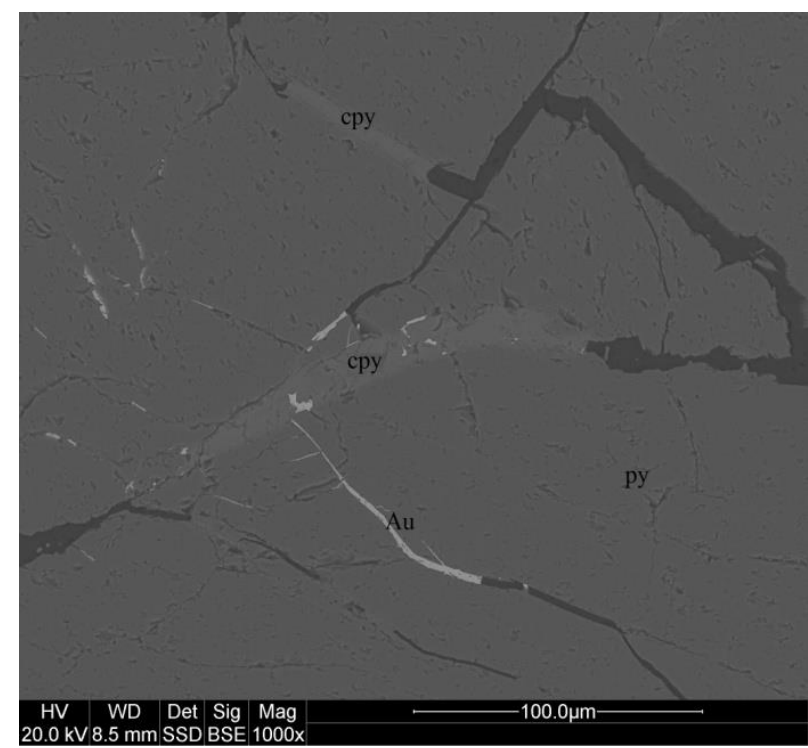

Fig. 7a. BSE image showing position of electrum $(\mathrm{Au})$ in relation to pyrite (py) and chalcopyrite (cpy). Reflected light

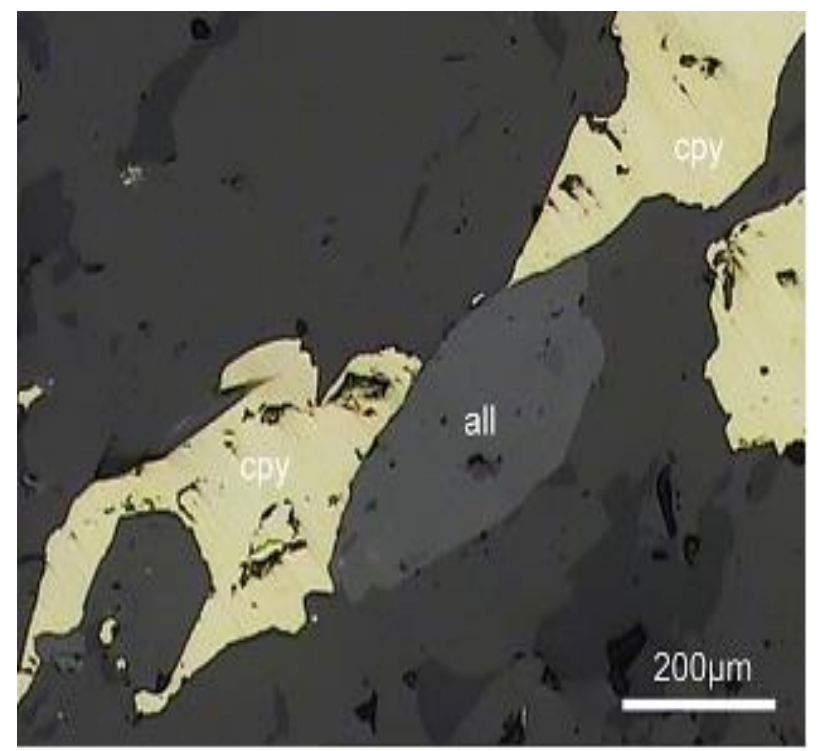

Fig. 7b. Intergrowth of allanite (all) with chalcopyrite (cpy). Reflected light

Using the data in the table 1, the correlations between different elements were performed, and their coefficients are summarized in table 2. All the values of correlation coefficients (R) higher than 0.5 are mark in bold. According to the statistics background and excluding the relations between sulfur and iron with other elements, we consider only the strong relations, it means that the relations, which $\mathrm{R}$ is higher than 0.7 . The correlation coefficients between $\mathrm{Cu}$ and $\mathrm{Ag}, \mathrm{Te}, \mathrm{Bi}, \mathrm{Pb}$ and $\mathrm{Au}$ are higher than 0.7 and equal to 0.94, 0.94, 0.90, 0.82 and 0.73 respectively (Tab. 2, and Fig. 8a-8e). Cu, Au, and Ag belong to the chalcophile elements group, which naturally prefer to bond with sulfur to form the resist compounds (Palyanova et al., 2018; Gas'kov, 2017). Au and $\mathrm{Ag}$ often occur together with pyrite, chalcopyrite and pyrrhotite (Fig. 7a). These elements are in a strong correlation $(\mathrm{R}=0.79$, Fig. 9$)$ indicating high similarity in their geochemical properties.

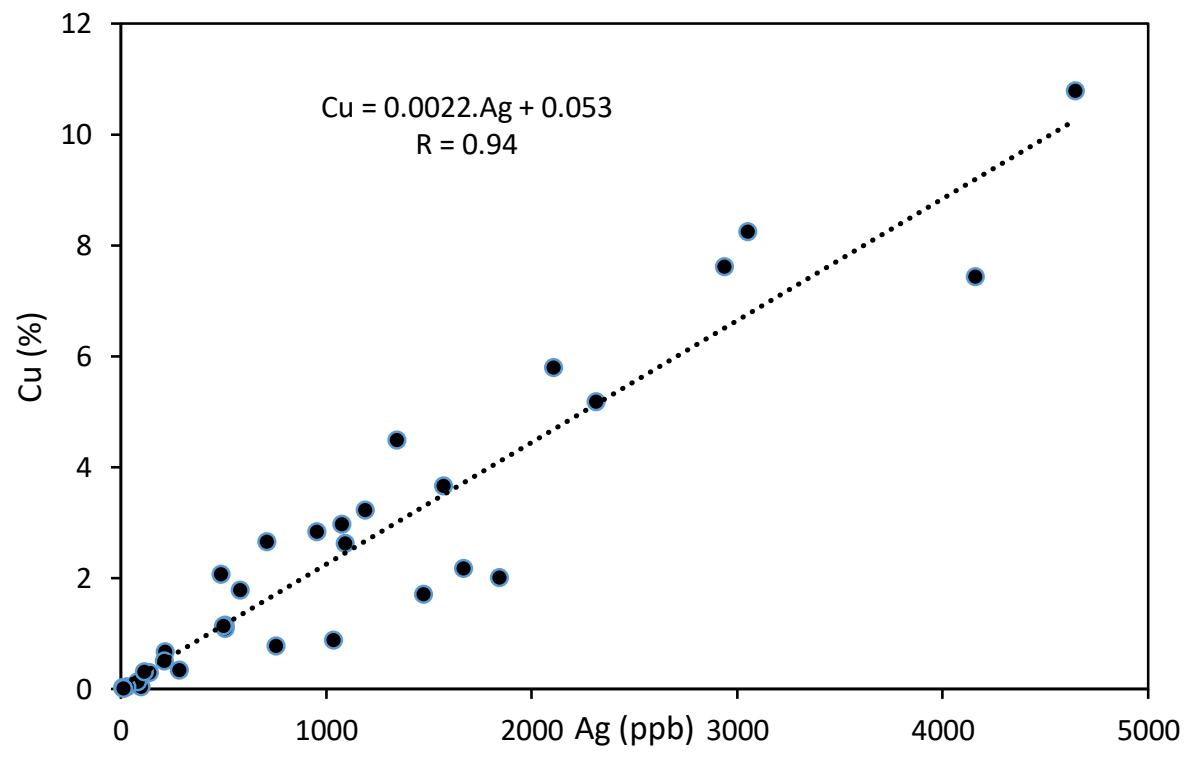

Fig. 8a. The correlation between $\mathrm{Cu}$ and $\mathrm{Ag}$ concentration 


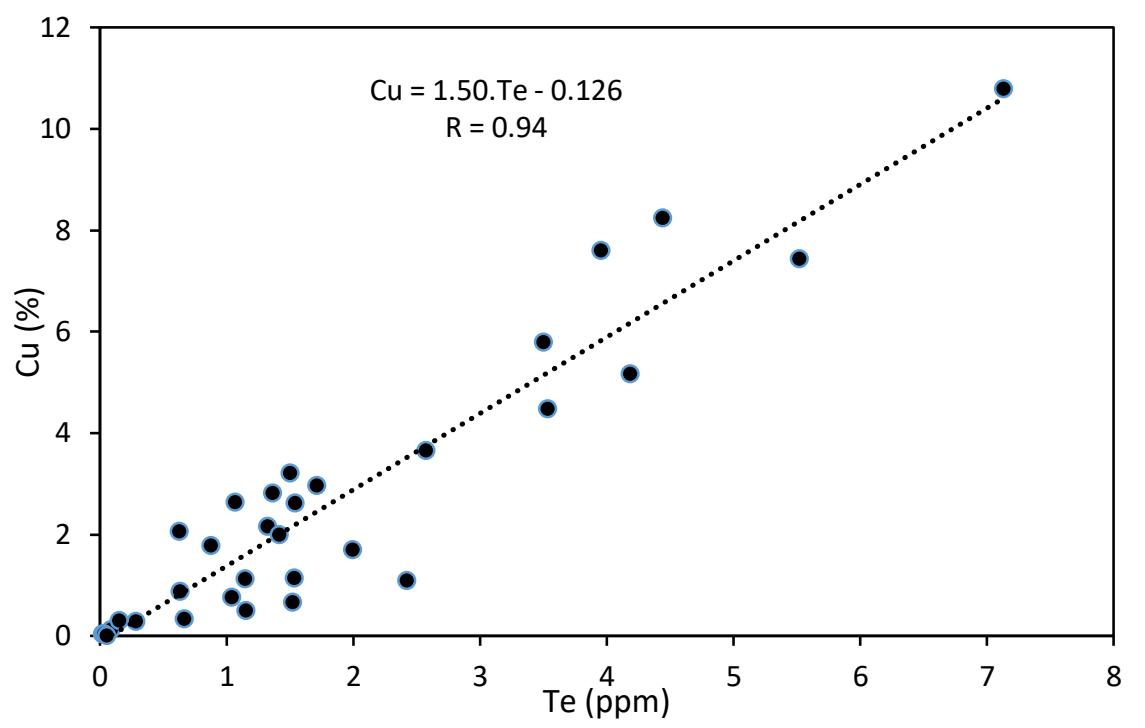

Fig. 8b. The correlation between $\mathrm{Cu}$ and Te concentration

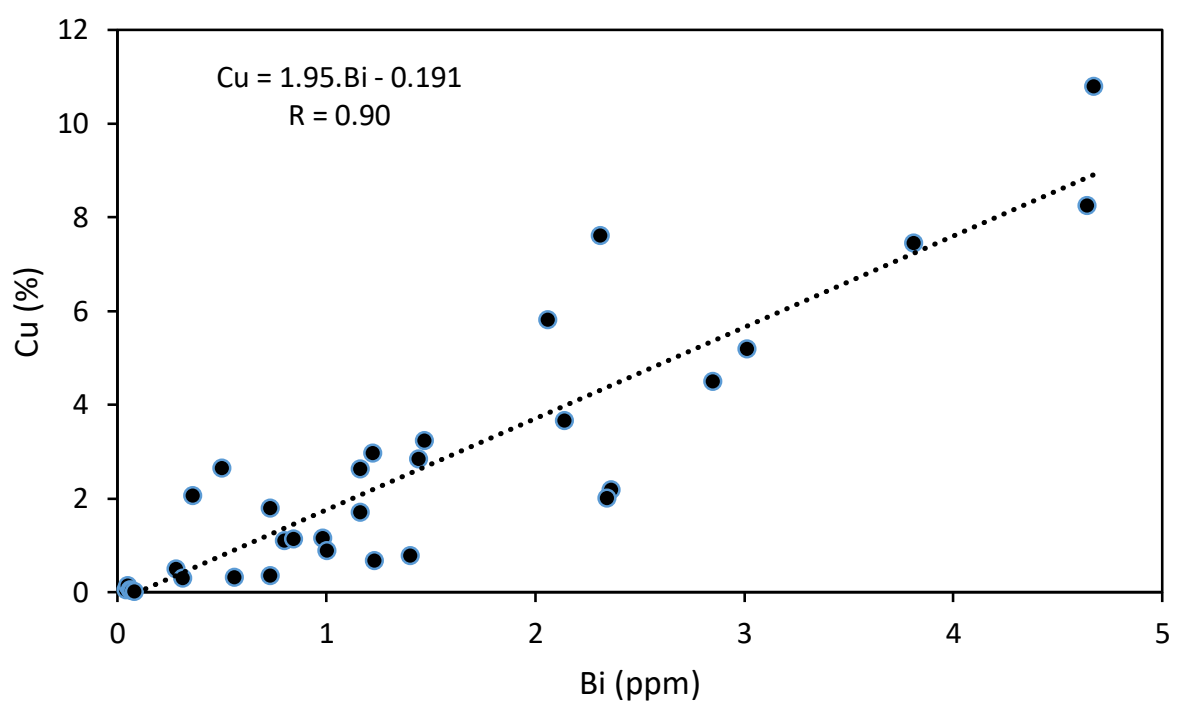

Fig. 8c. The correlation between $\mathrm{Cu}$ and $\mathrm{Bi}$ concentration

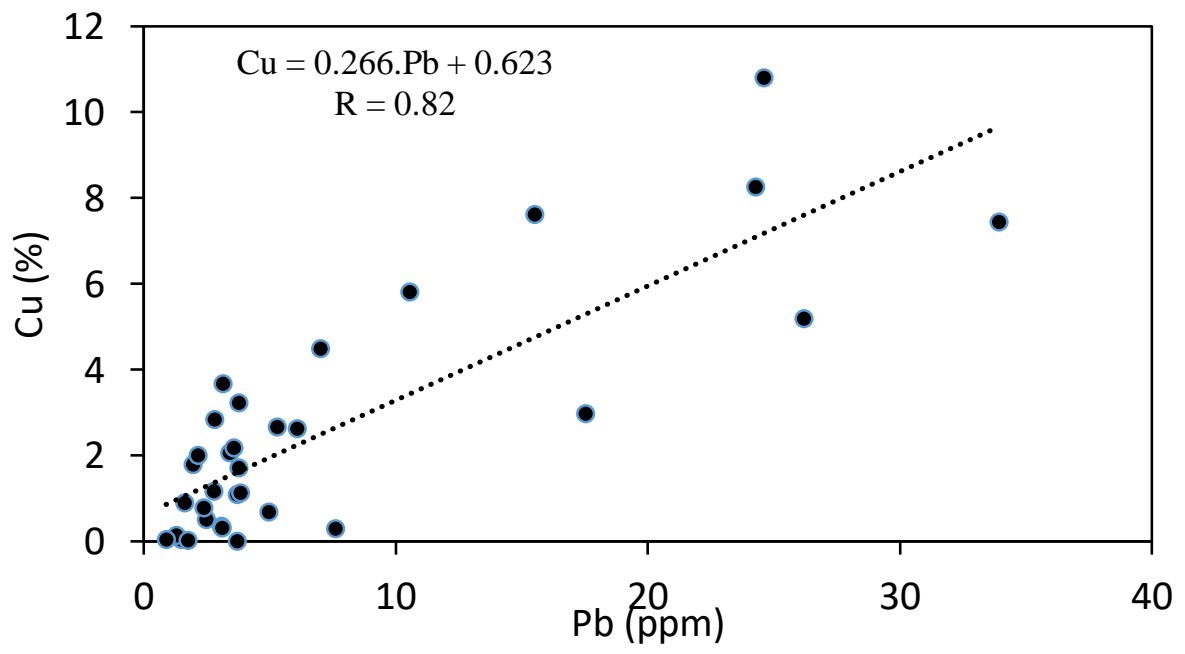

Fig. 8d. The correlation between $\mathrm{Cu}$ and $\mathrm{Pb}$ concentration 


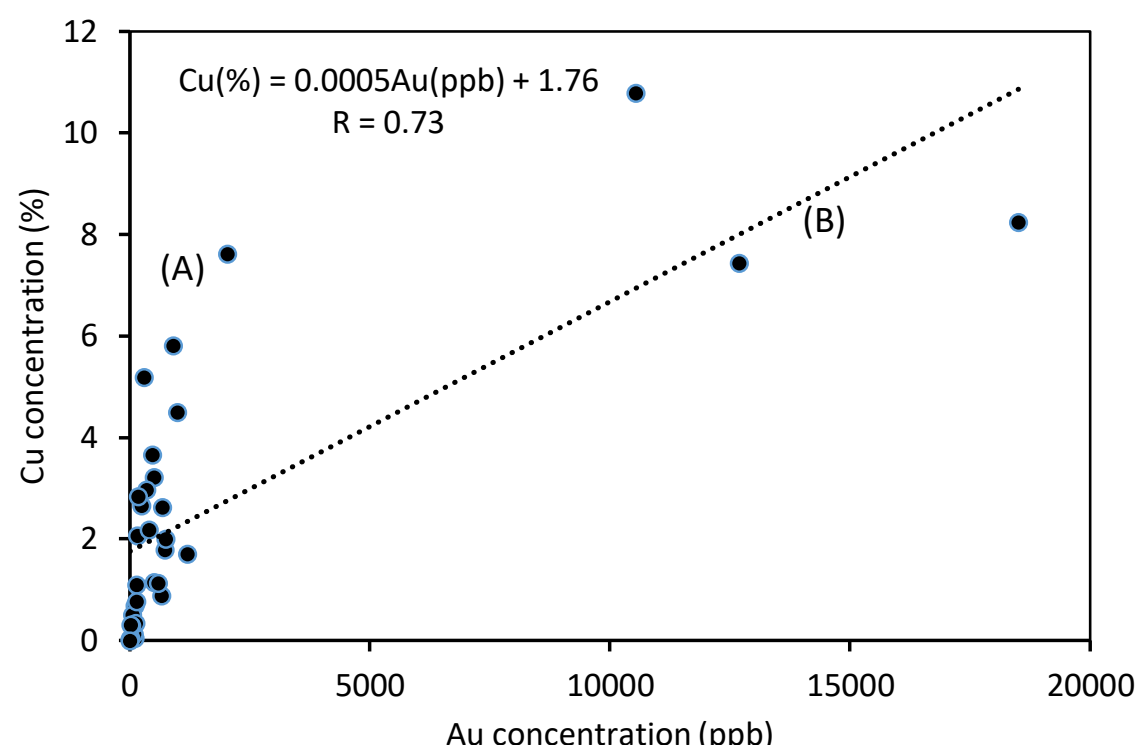

Fig. 8e. The correlation between $\mathrm{Cu}$ and $\mathrm{Au}$ concentration

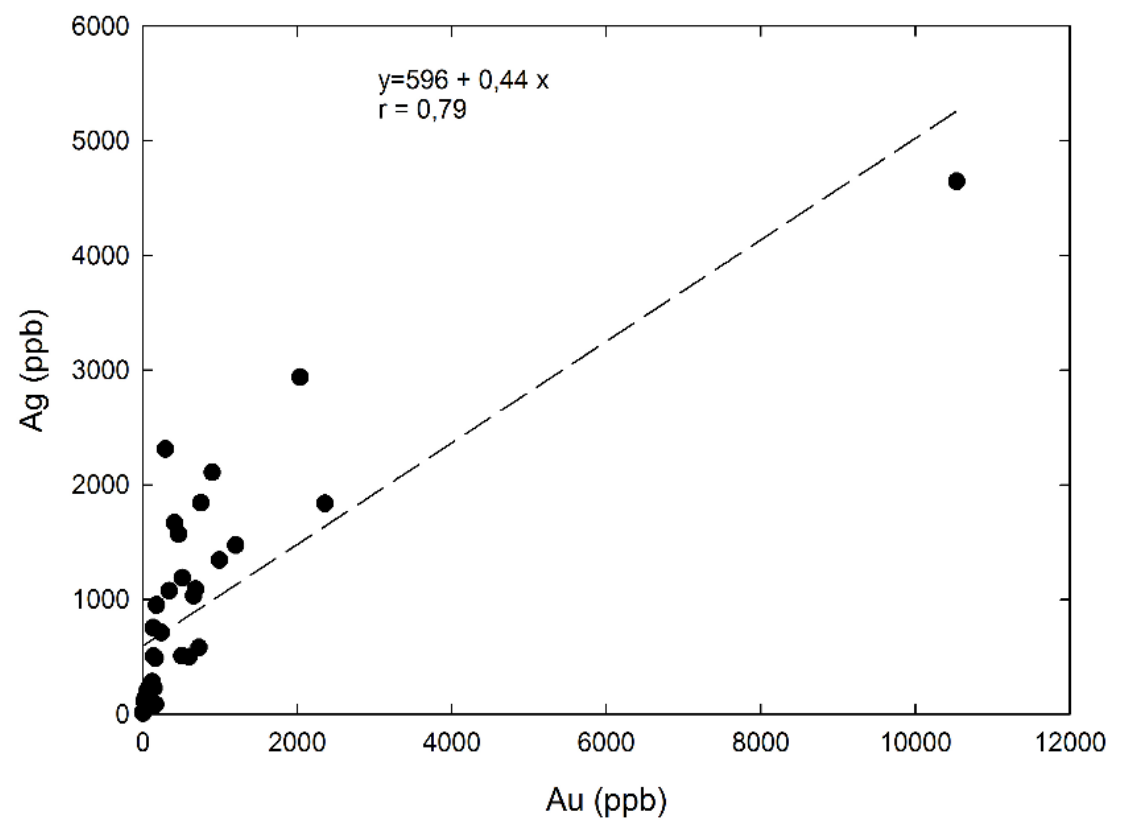

Fig. 9. Plot of relation between $\mathrm{Au}$ and $\mathrm{Ag}$

$\mathrm{Au}-\mathrm{Ag}$ alloy often commonly occurs in micro-vein form in gold and copper minerals with trace elements of $\mathrm{Hg}$ (Knight and Leitch, 2001; Gas'kov et al., 2001). The correlation $\mathrm{Cu}$ - $\mathrm{Au}$ is lower than $\mathrm{Cu}-\mathrm{Ag}$ (compare Fig. $8 \mathrm{a}$ and Fig. 8e), indicating a part of $\mathrm{Au}$ formed separately as native form, and other part of $\mathrm{Au}$ crystalized together with $\mathrm{Ag}$ and $\mathrm{Cu}$. In other hand silver is more affine to sulfur than to gold and tend to enter sulfide minerals (Gas'kov, 2017). These processes are depended on the content of $\mathrm{Au}, \mathrm{Ag}$ and $\mathrm{Cu}$ in the hydrothermal fluid, crystallization temperature and sulfur fugacity (Palyanova et al., 2018; Gas'kov, 2017). The significantly high concentrations of $\mathrm{Au}(>10000 \mathrm{ppb})$ and $\mathrm{Ag}(>4000 \mathrm{ppb})$ are observed only in the samples of the $\mathrm{Cu}-\mathrm{Fe}$ massive ore, suggesting electrum intergrowth with sulfide minerals mainly in breccias ores. The high correlation coefficients are observed also for $\mathrm{Cu}-\mathrm{Te}(\mathrm{R}=0.94)$ and $\mathrm{Cu}-\mathrm{Bi}(0.90)$ (Tab. 2 and Fig. 8b, 8c). In intrusive fluid high tellurium can bind silver and gold and forms as silver and gold tellurides (Gas'kov, 2017). In the Sin Quyen copper deposit Te and Bi are trace elements with $1.9 \mathrm{ppm}$ and $1.4 \mathrm{ppm}$ of average concentration respectively. These concentrations are comparable with that in the other IOCG deposits in the World (Mikulski, 2014). Generally presence of Te and Bi in IOCG deposit is related to the Au-Ag-Bi-Te-Pb mineral association as arsenopyrite and polymetallic sulfite (Mikulski, 2014). In the deposit, intergrowth of 
bismuthinite $\left(\mathrm{Bi}_{2} \mathrm{~S}_{3}\right)$ with chalcopyrite (Fig. 10), indicating that these minerals crystalized at the similar temperature.

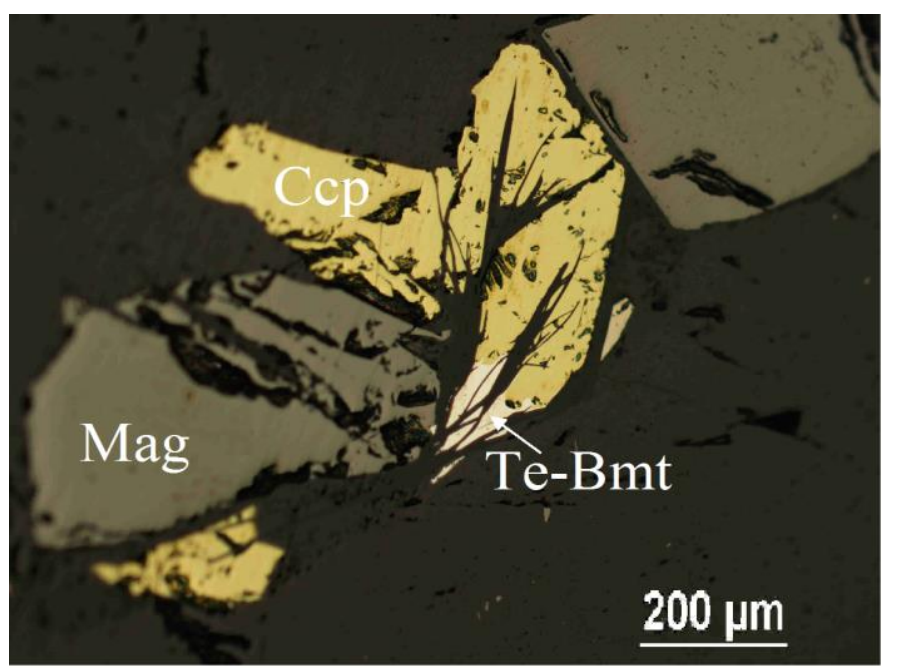

Fig. 10. Te-Bismuthinite (Te-Bmt) with chalcopyrite (Ccp) in reflected light

In the weathered zone bismuthinite reacts with water and is transform into the bismite $\left(\mathrm{Bi}_{2} \mathrm{O}_{3}\right)$ or bismutite $\mathrm{Bi}_{2}\left(\mathrm{CO}_{3}\right) \mathrm{O}_{2}$ (Gruszczyk, 1984). Figure $8 \mathrm{~d}$ presents the relation between $\mathrm{Cu}$ and $\mathrm{Pb}$ with $\mathrm{R}=0.82, \mathrm{~Pb}$ is also specific chalcophile elements. The $\mathrm{Pb}$, Te and Bi concentrations are in order of several ppm (Tab. 1), therefore the elements in the IOCG deposits are regarded as the impurity and not classified as co-product elements (Barton, 2014).

Generally uranium and thorium minerals such as uraninite, thorite, thorianite and allanite are often present in IOCG deposits. Although low grade enough, the world' uranium greatest resource is in the IOCG Olympic Dam deposit in Australia (9.2 Gt @ 270 ppm U), the smaller uranium resources occur in other IOCG assemblages including the Kangdian metallogenic province in SW China, Qiaoxiahala deposit in Jungar region, NW China, Ayazmant skarn deposit in Ayvalik (Balikesir), Turkey and the others (Hitzman and Valenta, 2005; Chen et al., 2015; Li et al., 2014; Oyman, 2010). The main bearing uranium in the Sin Quyen deposit is uraninite. This mineral often exists as an intergrowth with chalcopyrite, magnetite, and allanite in the $\mathrm{Cu}-\mathrm{Fe}$ massive ore (Fig. 11). Owing the high uranium concentration the Sin Quyen deposit was discovered by radiometric survey (Ta, 1975). The correlation coefficient of the $\mathrm{Cu}-\mathrm{U}$ amounts to 0.78 (Tab. 2). Similar correlation coefficient of $\mathrm{Cu}-\mathrm{U}$ was observed in the case of the Polish copper mines in Lubin mining district (Niewodniczański, 1981; Piestrzyński, 1989).

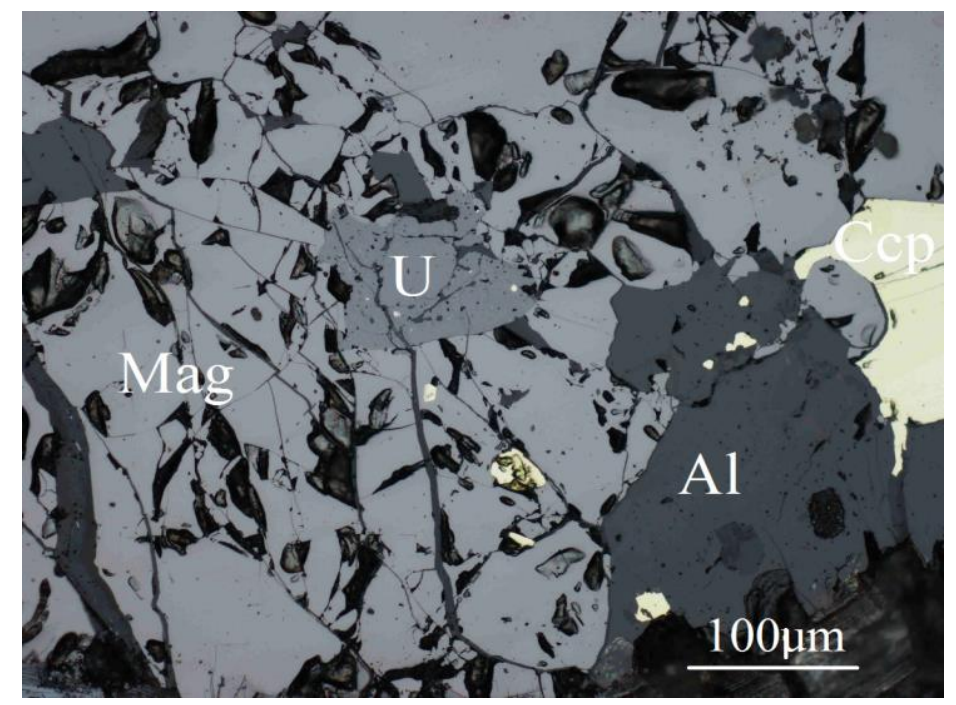

Fig. 11. Intergrowth of uraninite (U) with magnetite (Mag), chalcopyrite (Ccp) and allanite (Al). Reflected light 
Iron is the most basic element in the studied deposit, its concentration varies from near 1 percent up to above 40 percent. However, the coefficients of the correlation between this element and other elements were relatively low $(\leq 0.6)$. The low correlation coefficients of Fe with other elements in the study deposit were also reported by Gas'kov et al. (2012). The weak correlation of Fe probably is connected with the geochemical property of this element. In nature Fe can occur at the state of $2+$ or $3+$, and rarely 0 . Depending on the redox and chemical condition, Fe can bond with sulfur or oxygen and form sulfate or sulfide or oxide compounds. In Sin Quyen deposit there are many Fe-bearing minerals, such as rock forming and chalcopyrite, bornite, pyrrhotite, pyrite and magnetite indicating that in the deposit there were inhomogeneous fluid. Several crystallization stages accompanied with different geological and crystallization conditions have been recognized in the deposit (Gas'kov et al., 2012; Pieczonka et al., 2015; Li et. al., 2018). Additionally there are some zones characterized with different major minerals (Gas'kov et al., 2012; Pieczonka et al., 2015). Using the archival data reported by $\mathrm{Ta}$ (1975), the plot of the relation between two principal elements $\mathrm{Cu}$ and $\mathrm{Fe}$ in the deposit is shown in figure 12 .

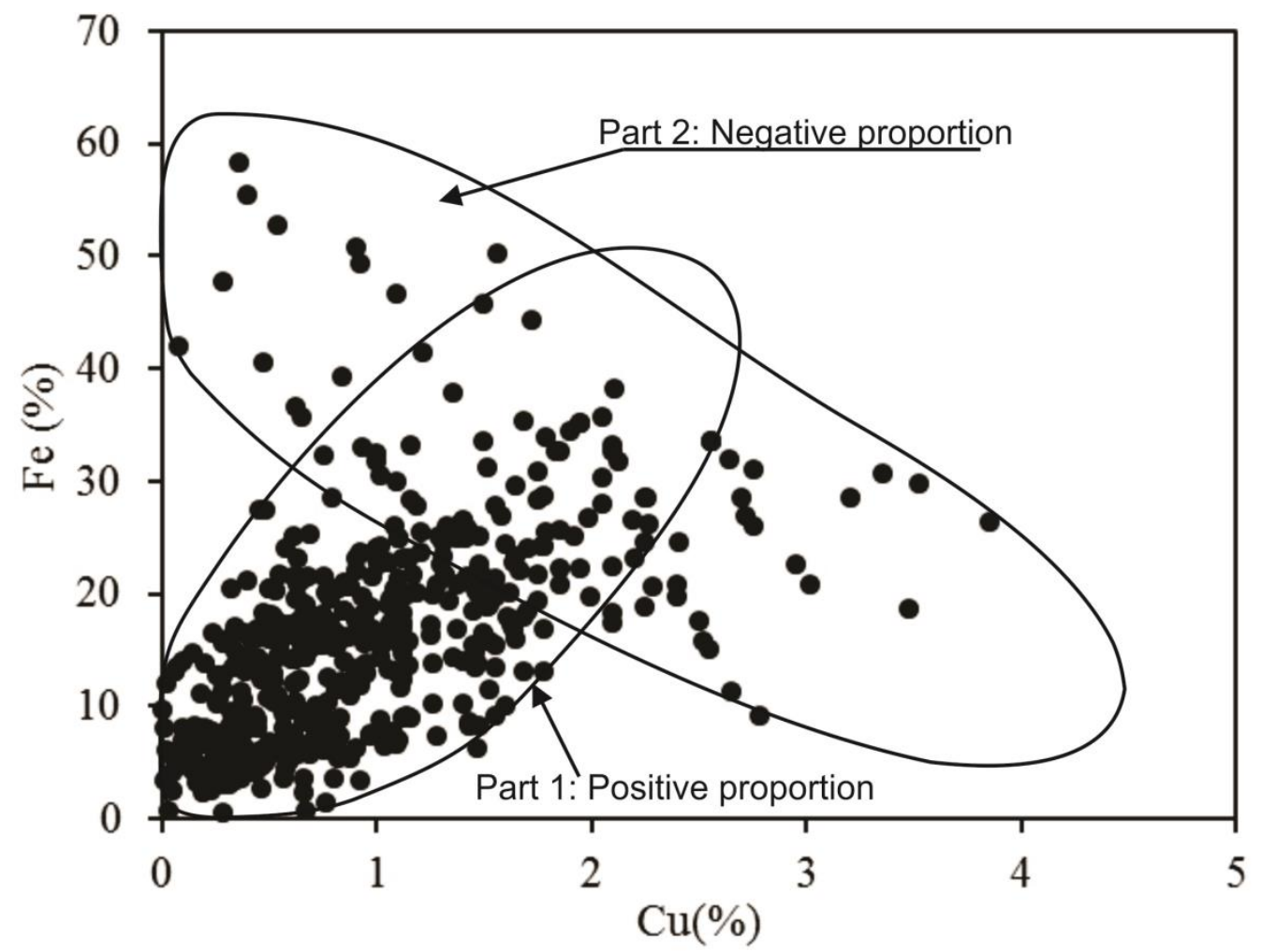

Fig. 12.The plot of relation between $\mathrm{Fe}$ and $\mathrm{Cu}$ concentration (the data were taken from the paper published by Ta (1975))

The Cu-Fe plot (Fig.12) can be divided into two parts. In the first part there are relatively low concentrations of both $\mathrm{Fe}$ and $\mathrm{Cu}$ and characterized by the linearly increasing of $\mathrm{Fe}$ with $\mathrm{Cu}$. The second part $\mathrm{Fe}$ is dominating and decreasing with $\mathrm{Cu}$. Two mentioned parts could be corresponded to the two types of ores described by Gas'kov et al. (2012). The samples with positive correlation belong to the first zone and the most of samples with negative correlation are within the second deposit part.

$\mathrm{Co}$ and $\mathrm{Ni}$ are the typical siderophile elements and often occur in the sulfoarsenides or with Fe in pyrrhotite or pyrite, but their grades in IOCG deposit are rarely exceed 100 ppm (Barton, 2014; Gas'kov, 2017). In the Sin Quyen deposit the concentrations of these elements range from a few ppm up to $300 \mathrm{ppm}$ (Tab. 1). The maximum concentrations are far below of the economic grade of $\mathrm{Co}, \mathrm{Ni}$ deposit. The correlation coefficient is equal to 0.9 (Tab. 2) and the view of the plot of the Ni-Co couple is shown on figure 13a. The high correlation coefficient reflects the close mineralogical association of $\mathrm{Co}$ and $\mathrm{Ni}$ and the comparable concentration ranges of these elements in the study deposit. The correlation coefficient of the Fe-Co pair amounts only to 0.62 (Fig. 13b), but the value of the correlation coefficient of the Co-S pair is equal to 0.83 (Tab. 2, and Fig. 13c), suggesting that Co mostly occurring as substitution at the sulfides. 


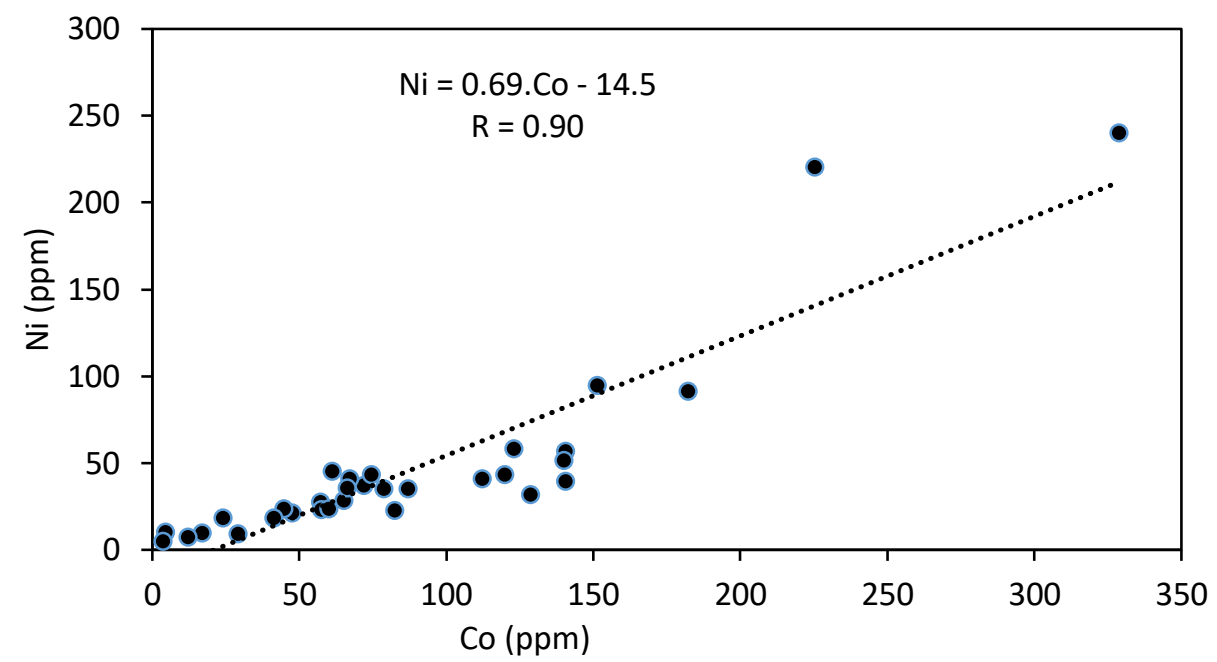

Fig. 13a. Plot of relation between $\mathrm{Co}$ and $\mathrm{Ni}$

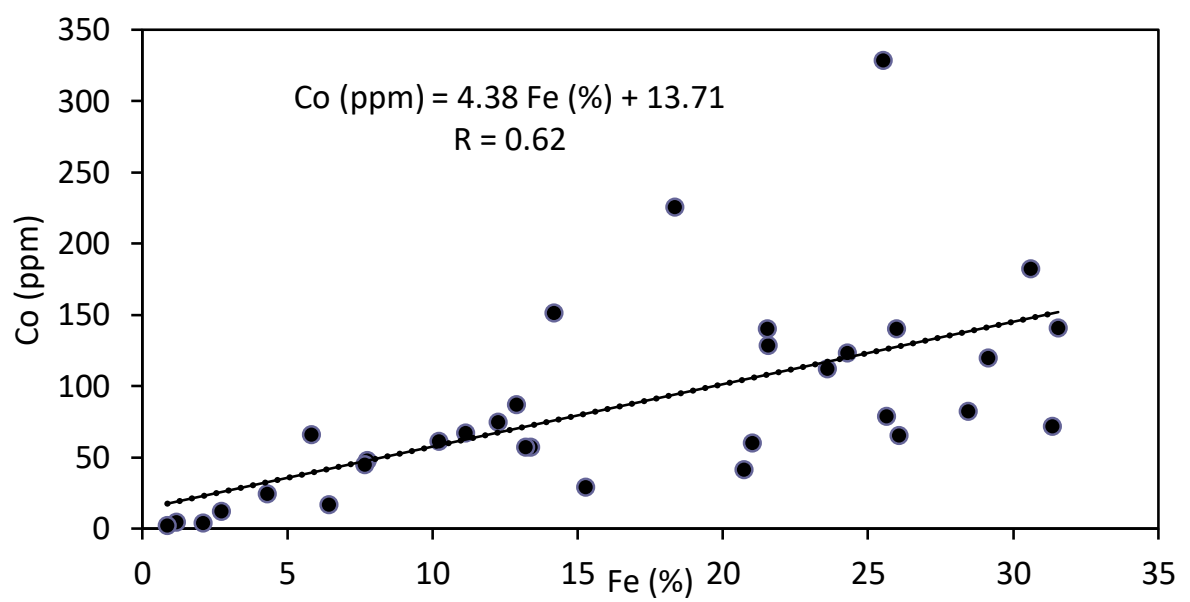

Fig. 13b. Plot of relation between Fe and Co

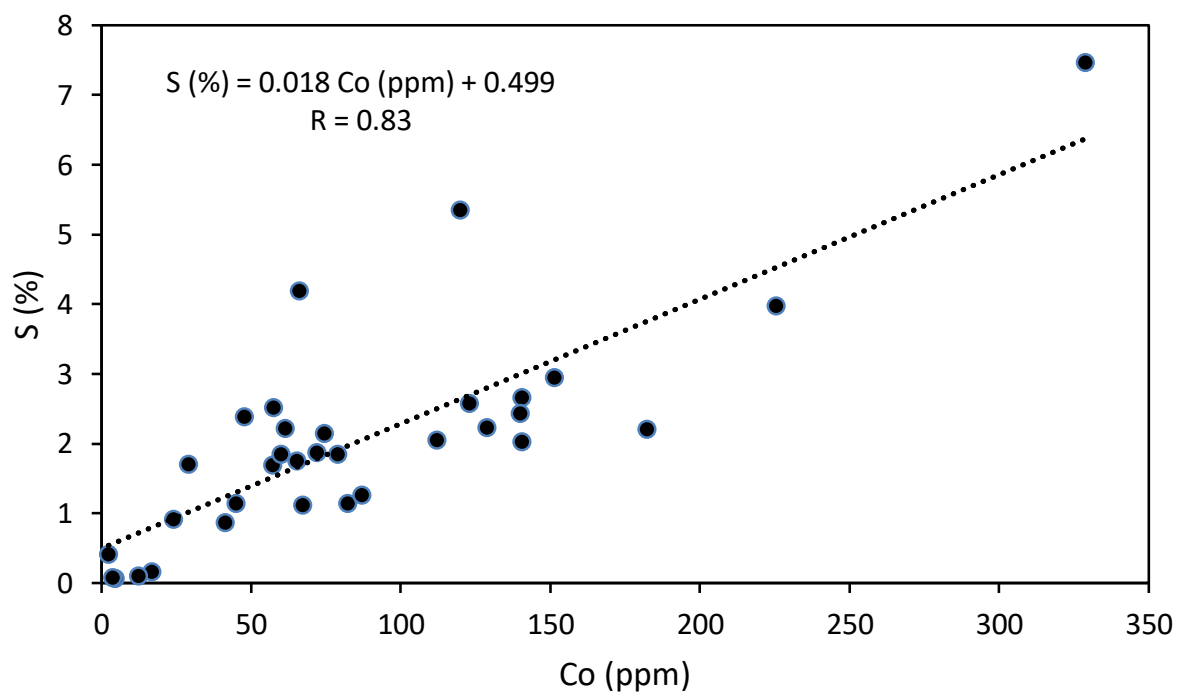

Fig. 13c. Plot of relation between Co and S

Natural radioactive elements often play very important roles in the geophysical survey especially for deposits rich in these elements. The average activity concentrations of ${ }^{40} \mathrm{~K},{ }^{226} \mathrm{Ra}$ and ${ }^{232} \mathrm{Th}$ in the Sin Quyen deposit were recorded at 496, 691 and $59 \mathrm{~Bq} / \mathrm{kg}$ respectively. The correlation coefficients of the pairs: U-Cu, U-Pb, 
U-Au, U-Ag, U- Bi and U-Te amount to $0.78,0.97,0.78,0.81,0.75$, and 0.78 respectively (Table. 2 and Fig. 14a-14f). Such high correlation enable us to determine the mentioned nonradioactive elements in the solid samples through measurements of uranium and save significantly the analyze costs. In the Sin Quyen deposit, the principal radioactive element is uranium (Nguyen et al., 2016), the main mineral bearing uranium is uraninite, its presence is often observed within the copper massive ores (Ishihara et al., 2011; Pieczonka et al., 2015). The high correlation coefficient of $\mathrm{U}-\mathrm{Pb}(\mathrm{R}=0.97$, Fig. $14 \mathrm{~b})$ probably is connected with the ${ }^{206} \mathrm{~Pb}$ isotope (the last isotope in the uranium series), which principally contributes in the content of the whole of lead in the deposit. The good correlation between $\mathrm{U}$ and $\mathrm{Au}, \mathrm{Ag}, \mathrm{Bi}$ and $\mathrm{Te}$ suggests the minerals currying these elements principally crystalized at the similar temperatures. According to Gas'kov (2008) the crystallization temperatures of the mentioned elements bearing minerals: uraninite, tellurobismuthite, sulfoaresenides varied from 200 to $75{ }^{\circ} \mathrm{C}$.

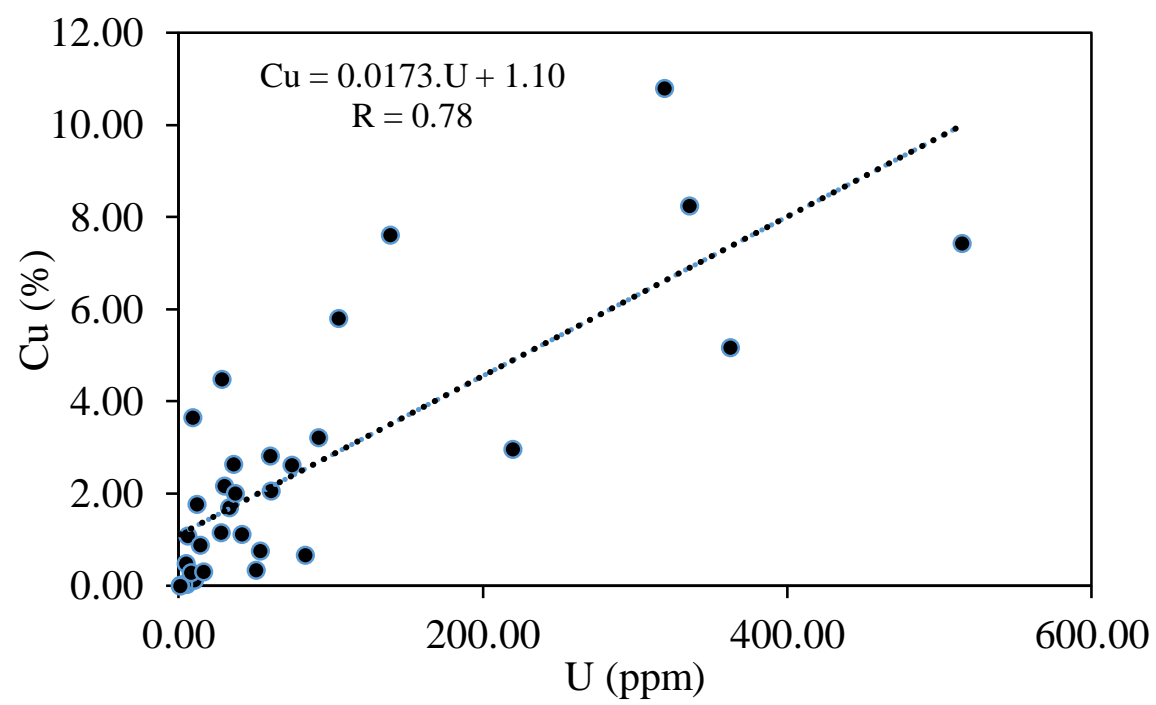

Fig. 14 a. The correlation between $\mathrm{U}$ and $\mathrm{Cu}$ concentration

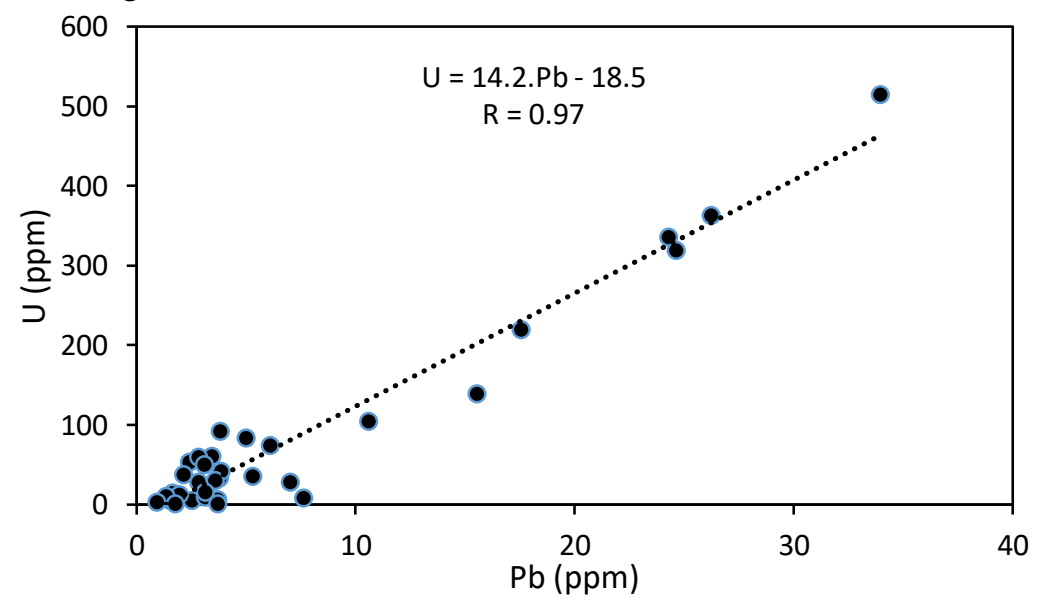

Fig. 14b.The correlation between $\mathrm{U}$ and $\mathrm{Pb}$ concentration 


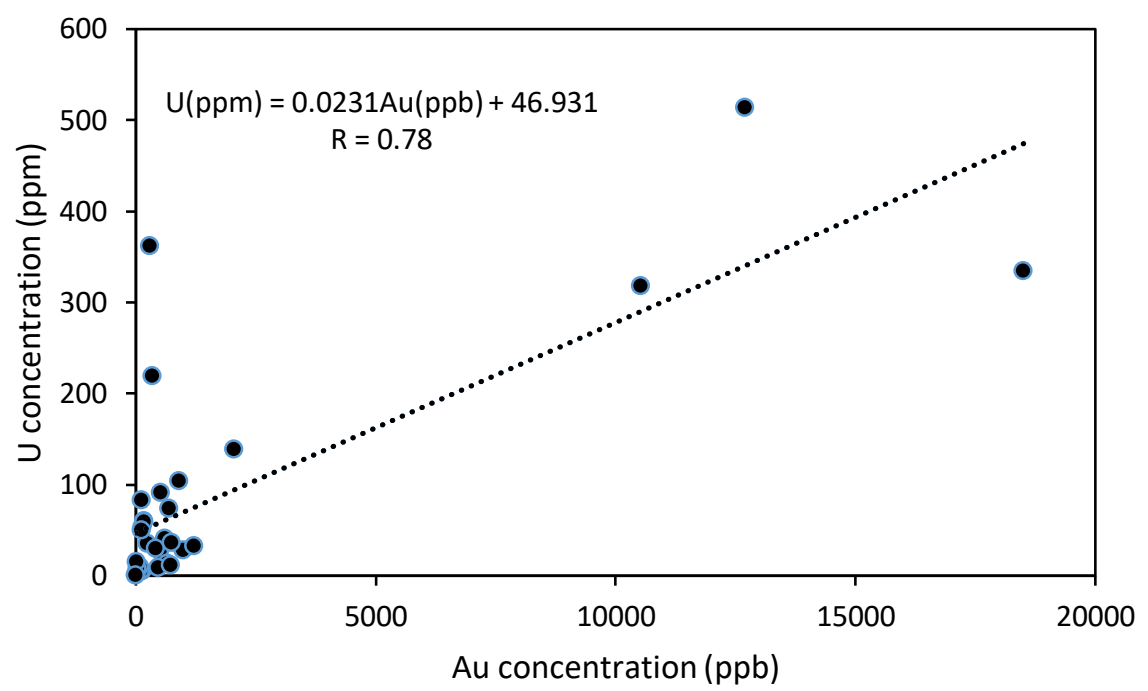

Fig. 14c. The correlation between $\mathrm{U}$ and Au concentration

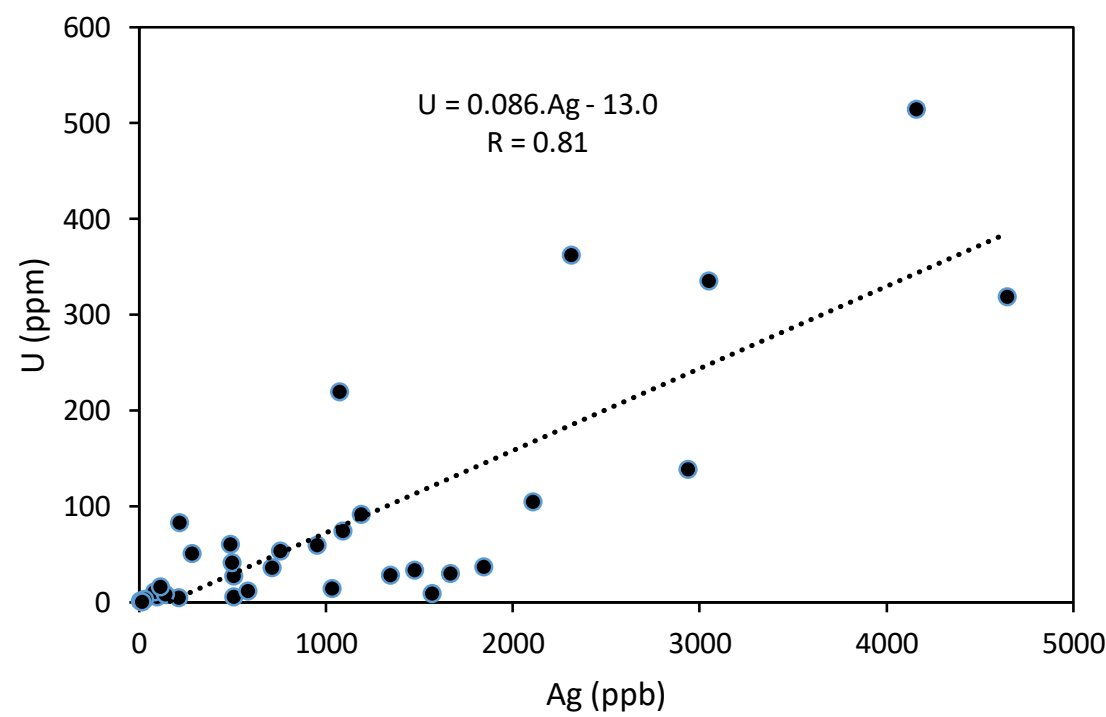

Fig. 14d. The correlation between $\mathrm{U}$ and $\mathrm{Ag}$ concentration

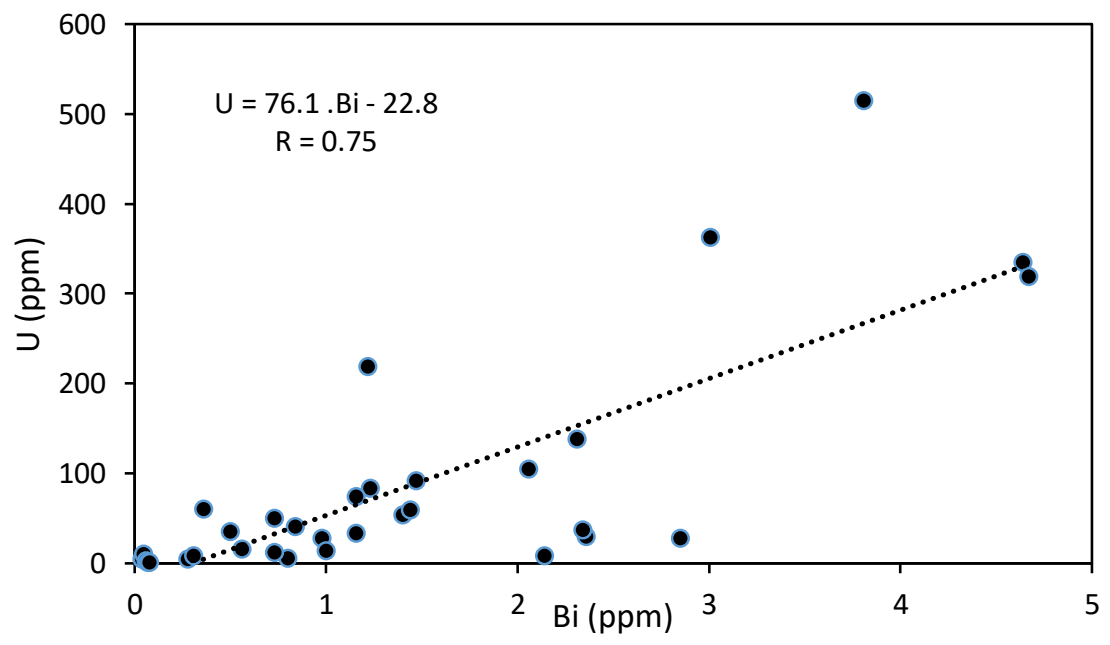

Fig. 14e. The correlation between $\mathrm{U}$ and $\mathrm{Bi}$ concentration 


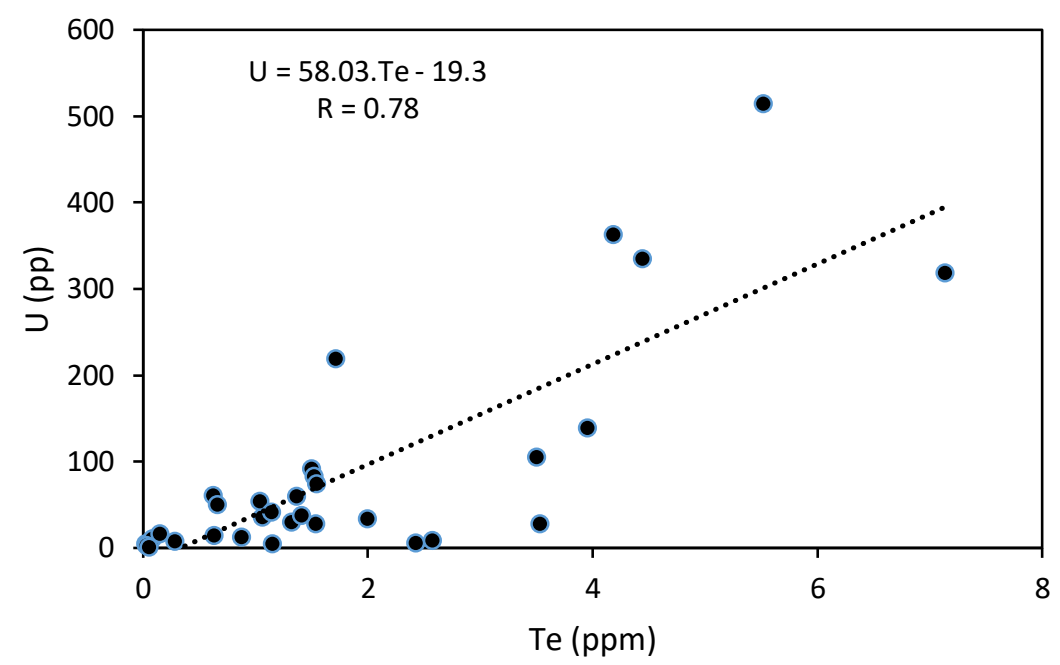

Fig. 14f Relation between $\mathrm{U}$ and Te

The reservoir of the rare earth elements (REE) is on the third place after Fe and $\mathrm{Cu}$ in the Sin Quyen deposit (Ta, 1975; McLean, 2001; Ishihara et al., 2011; Gas'kov et al., 2012; Li and Zhou, 2018). The main REE bearing mineral is allanite (Fig. 11). Usually it occurs either at low concentrations, 1-2 vol\%, or very rarely as a major mineral. The average content of allanites in the ore is on the level of $0.98 \mathrm{wt} \%$ (Pieczonka, et al., 2015). There is no correlation with other element observed, suggesting allanites were formed separately from the sulfide and oxide ores (Gas'kov et al., 2012).

In the deposit there are two groups of allanites (Fig. 15a-15d), the outer rim is younger. Different tints in the grey color show mosaic textures of allanite crystals. This can be interpreted either as a change in the fluid composition during crystallization, or changes in the composition during Na-alteration (Li and Zhou, 2018). The older allanite group is with REE content from 23 to $27 \%$, and the younger with 19 to $23 \%$ and higher amounts of $\mathrm{Al}_{2} \mathrm{O}_{3}, \mathrm{CaO}$ and $\mathrm{SiO}_{2}$ (McLean, 2011; Pieczonka, et al., 2015). The allanites can be classified as La-Ce-ferriallanite, and a variety with low $\mathrm{Y}, \mathrm{U}$ and Th. The difference of the mentioned two groups could be resulted from the alteration processes occurring in the study deposit.

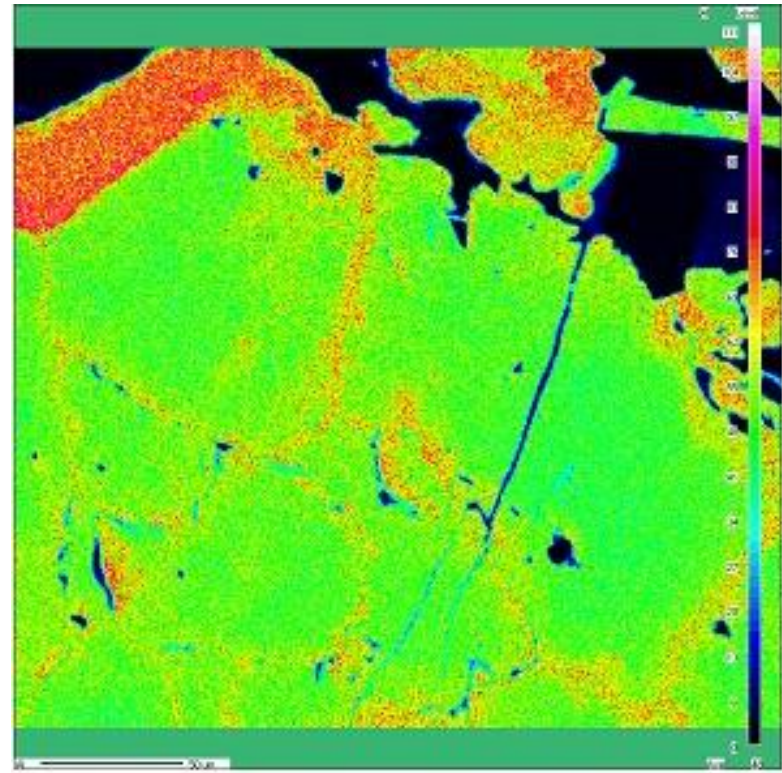

Fig.15a. Contour map of $\mathrm{Al}$ in allanites

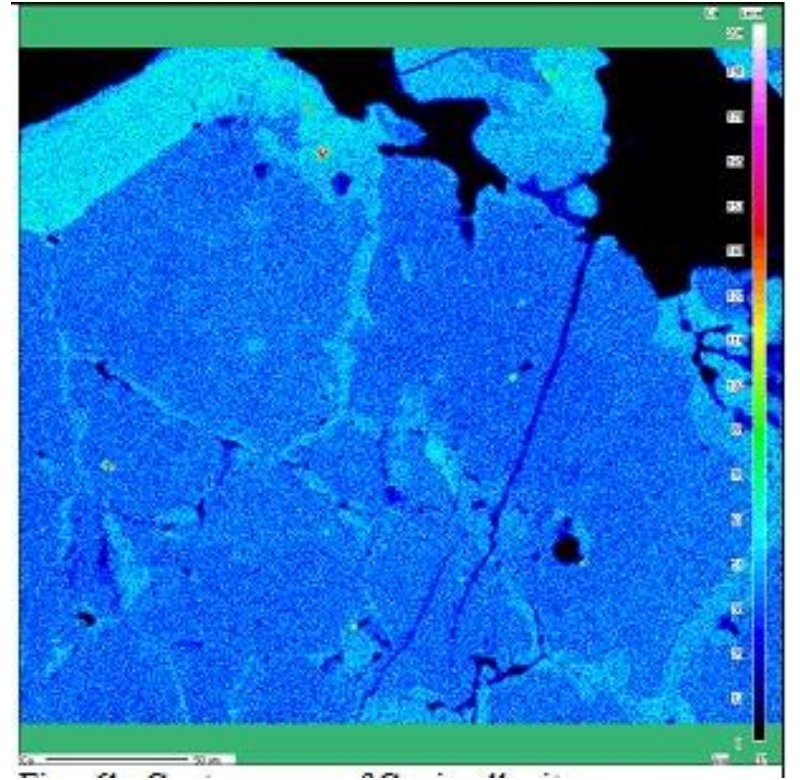

Fig. 15b. Contour map of $\mathrm{Ca}$ in allanites 


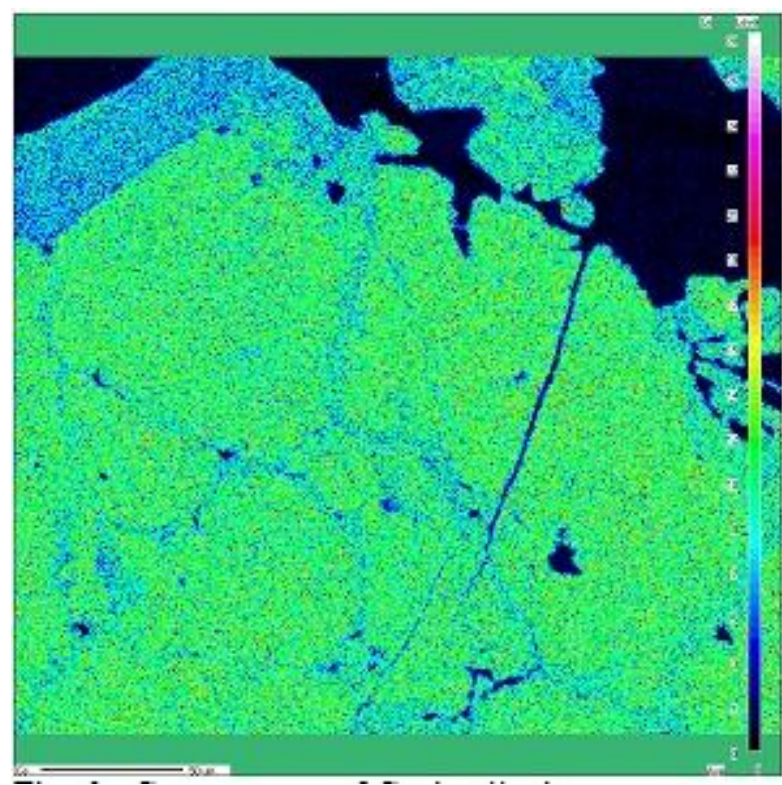

Fig. 15c. Contour map of Ce in allanites

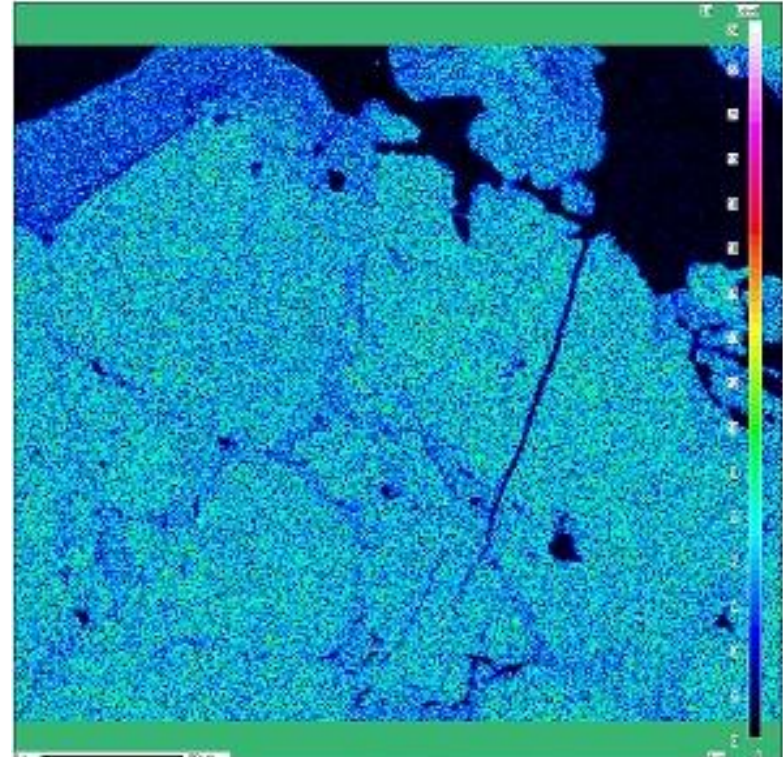

Fig. $15 \mathrm{~d}$ Contour map of $\mathrm{La}$ in allanites

Sulfur is very interesting element in IOCG deposit, its average concentration in the deposit amounts to $2.04 \%$ (Tab. 2). The sulfur minerals are dominating in the deposit, but excluding relation between $\mathrm{S}$ and Co, the correlation coefficients of the relation between sulfur and other major, minor as well as trace elements are below 0.5 (Tab. 2). The relation between $\mathrm{S}$ and other elements is the first time considered in this paper. In general the crystallization of the sulfur minerals requires a relatively oxidized $\left(\mathrm{SO}_{4}{ }^{2-}>\mathrm{H}_{2} \mathrm{~S}\right)$ and low in total sulfur (Barton, 2014). In IOCG deposit sulfur occurs in different sulfides (pyrite, chalcopyrite, pyrrhotite). Due to high chemical active, sulfur is easily bound with different elements to form different minerals. Therefore the total sulfur is spread into many compounds and no clear correlation between this elements with the others. The suggestion was tested by the correlation between sulfur and the sum of $\mathrm{Fe}$ and $\mathrm{Cu}(\mathrm{Fe}+\mathrm{Cu})$, which correlation coefficient $\mathrm{R}$ is equal to 0.56 (Fig. 16), the value is far higher than that of the correlation between $\mathrm{Cu}$ and other single element.

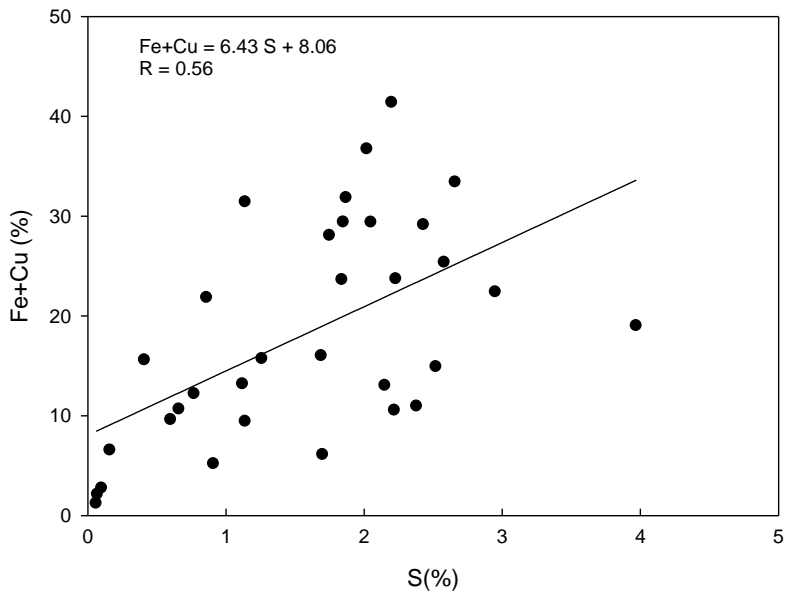

Fig. 16. Plot of relation between $\mathrm{S}$ and $(\mathrm{Cu}+\mathrm{Fe})$ 


\section{Conclusions}

Generally the statistic analyze is very important in the most practice matters. In the Earth sciences the statistic calculus is named as geostatistics, which consist in the probability and statistic correlation between different parameters of the geological objects. The authors of this paper attempted to deal with the relations between the major, minor and trace elements focusing on the strong correlations and inspected relations. Based on the presented results and calculated correlation coefficients as well as geological and geochemical analyze, some conclusions are emerged as follow:

1. The strong correlations between the elements belong to the chalcophile group, to which $\mathrm{Cu}, \mathrm{Ag}, \mathrm{Au}, \mathrm{Pb}$, $\mathrm{Bi}$ and Te belong. The correlation coefficients between the elements in this group are higher than 0.7 and not sensitive on the ranges of the element concentrations.

2. The correlation between $\mathrm{Fe}$ and other elements even with $\mathrm{Co}$, and $\mathrm{Ni}$, which belong to the siderophile group is very weak or not observed. The phenomena can be consequence of the chemistry property of iron and geological as well as geochemical conjunctures in the IOCG Sin Quyen deposit. It worth adding there is strong correlation between $\mathrm{Co}$ and $\mathrm{Ni}$, the reason is that both elements not only have close mineralogical association but also their grade ranges are comparable in the deposit.

3. Between $\mathrm{Cu}$ and $\mathrm{Fe}$ there are clearly two relations, one is positive proportion and the second is negative proportion, the two relations probably are connected with the two horizontally separated parts of the Sin Quyen deposit.

4. There are strong correlation between uranium and several elements, such as: $\mathrm{Cu}, \mathrm{Ag}, \mathrm{Au}, \mathrm{Pb}, \mathrm{Bi}$ and $\mathrm{Te}$. The strong correlation between $\mathrm{U}$ and $\mathrm{Cu}, \mathrm{Ag}$ and $\mathrm{Au}$ can be resulted from the crystalization of uraninite together with the chalcopyrite and electrum minerals in the deposit.

5. There is very weak correlation or no between REE and other elements, the fact can be connected with allanite was formed separately from other minerals (Li et al., 2017).

6. No correlation between sulfur and major and minor or trace elements, the phenomena are resulted from the very chemical activity of this element. Sulfur is sensitive on the crystallization condition (temperature, pressure) and redox and easily reacts with many elements to form crystalized compounds, therefore there is no strong correlation between sulfur and other single element.

\section{Acknowledgment}

The work was made in the scope of the bilateral cooperation between Hanoi University of Mining and Geology (UMG) and AGH University of Science and Technology No.01/2012/HD-HTQTSP and foundered from USTAGH Krakow for financial support, grant no 11.11.140.161 and 11.11.140.645.

\section{References}

Barton, M.D., 2014. Iron oxide (-Cu-Au-REE-P-Ag-U-Co) systems. Elsevier, 515-537.

Chen, W.T., Zhou M.F., Gao, J.F., Hu, R., 2015. Geochemistry of magnetite from Proterozoic Fe-Cu deposits in the Kangdianmetallogenic province, SW China. Mineralium Deposita 50, 795-809.

Fabris, A., Wielen, S., Keeping, T., Gordon, G., 2015. Geochemical footprints of IOCG deposits beneath thick cover: insights from the Olimpic $\mathrm{Cu}$-Au province, South Australia. Conf. Materials of 27th International Applied Geochemistry Symposium (IAGS). Tuscon, 20-24.

Gandhi, S.S., 2003. An overview of the Fe oxide-Cu-Au deposits and related deposit types. CIM Montreal 2003 Mining Industry Conference and Exhibition, Canadian Institute of Mining, Technical Paper, CDROM.

Gas'kov, I.V., 2008. New data on the correlation of skarn and gold mineralization at the Tardan deposit (Northeastern Tuva). Russian Geology and Geophysics 49 (12), 923-931.

Gas'kov, I.V., 2017. Major impurity elements in native gold and their association with gold mineralization setting in deposits of Asian folded areas. Russian Geology and Geophysics 58, 1080-1092.

Gas'kov, I.V., Distanov, E.G., Kovalev, K.R., Akimtsev, V.A., 2001. Gold and silver in polymetallic deposits of northwestern Rudny Altai. Russian Geology and Geophysics 42 (6), 850-867.

Gas'kov, I.V., Tran,T.A., Tran, T.H., Pham T.D.,Nevolko, P.A., Pham, N.C., 2012. The Sin Quyen Cu-Fe-AuREE deposit (northern Vietnam) composition and formation conditions. Russian Geology and Geophysics 53, 442-456. 
Groves, D.I., Bierlein, F.P., Meinert, L.D., Hitzman, M.W., 2010. Iron oxide copper-gold (IOCG) deposits through Earth history: Implications for origin, lithospheric setting, and distinction from other epigenetic iron oxide deposits. Economic Geology 105, 641-654.

Gruszczyk, H., 1984. Science of ores [in Polish]. WG, Warszawa.

Hitzman, M.W., Oreskes, N., Einaudi, M.T., 1992. Geological characteristics and tectonic setting of Proterozoic iron oxide (Cu-U-Au-REE) deposit. Precambrian Res. 58, 241-287.

Hitzman, M.W., Valenta, R.K., 2005. Uranium in iron oxide-copper-gold (IOCG) systems. Economic Geology 100, 1657-1661.

Ishihara, S., Hideo, H., Mihoko, N.C., Pham, T.D., Pham, T.A., Tran, T.H., 2011. Mineralogical and chemicalcharacteristics of the allanite-rich copper and iron ores from the Sin Quyen mine, northern Vietnam. Bulletin of the Geological Survey of Japan 62 (5/6), 197 - 209.

Ivan, K.B., Thomas, K., Radostina, A., Colin, J.A., 2002. Morphogenesis and composition of native gold in the Chelopech volcanic-hosted $\mathrm{Au}-\mathrm{Cu}$ epithermal deposit, Srednogorie zone, Bulgaria. Mineralium Deposita 37, 614-629.

Jodlowski, P., Kalita, S., 2010. Gamma-Ray Spectrometry Laboratory for high-precision measurements of radionuclide concentrations in environmental samples. Nukleonika 55 (2), 143-148.

Knight, J., Leitch, C.H.B., 2001. Phase relations in the system $\mathrm{Au}-\mathrm{Cu}-\mathrm{Ag}$ at low temperatures, based on natural assemblages. The Canadian Mineralogist 39, 889-905.

Letnikova, E.F., Veshcheva, S.V., Proshenkin, A.I., Kuznetsov, A.B., 2011. Neoproterozoic terrigenous deposits of the Tuva-Mongolian massif: geochemical correlation, source lands, and geodynamic reconstruction. Russian Geology and Geophysics 52, 1662-1671.

Li, Q., Zhang, Z., Geng, X., Li, C., Liu, F., Chai, F., Yang, F, 2014. Geology and geochemistry of the Qiaoxiahala $\mathrm{Fe}-\mathrm{Cu}-\mathrm{Au}$ deposit, Junggar region, northwest China. Ore Geology Review 57, 462-481.

Li, X.C., Zhou, M.F., 2018. The nature and origin of hydrothermal REE mineralization in the Sin Quyen deposit, northwestern Vietnam. Economic Geology 113 (3), 645-673.

Li, X.C., Zhou, M.F., Chen, W.T., Zhao, X.F., Tran, M.D., 2017. Uranium-lead dating of hydrothermal zircon and monazite from the Sin Quyen Fe-Cu-REE-Au-(U) deposit, northwestern Vietnam. Mineralium Deposita 53(3), 399-416.

McLean, R.N., 2001. The Sin Quyen iron oxide-copper-gold-rare earth oxide mineralization of North Vietnam, in: T. M. Porter (Ed.), Hydrothermal Iron Oxide and Copper-Gold Related Deposits: A Global Perspective. PGC Publishing 2, 293-301.

Mikulski, S.Z., 2014. The occurrence of tellurium and bismuth in the gold-bearing polymetallic sulfide ores in the Sudetes (SW Poland), [in Polish with abstract in English]. Mineral Resources Management 30 (2), 15-34,

Nguyen, D.C., Le, K.P., Jodłowski, P., Pieczonka, J., Piestrzyński, A., Duong, H.V., Nowak, J., 2016. Natural Radioactivity at the Sin Quyen iron oxide copper gold deposit in North Vietnam, Acta Geophysica 64 (6), 2305-2321.

Niewodniczański, J., 1981. A radiometric analysis of nonradioactive ores [in Polish with summary in English]. Scien. Bull. The Stanisław Staszic Academy of Mininig and Metallurgy, No 303 "MathematicsPhysics-Chemistry". Cracow, Poland.

Nikiforova, Z.S., Gerasimov, B.B., Glushkova, E.G., Kazhenkina, A.G., 2018. Indicative features of placer gold for the prediction of the formation types of gold deposits (east of the Siberian Platform). Russian Geology and Geophysics 59, 1318-1329.

Oyman, T., 2010. Geochemistry, mineralogy and genesis of the Ayazmant Fe-Cu skarn deposit in Ayvalik, (Balikesir), Turkey. Ore Geology Review 37, 175-201.

Palyanova, G.A., Murzin, V.V., Zhuravkova, T.V., Varlamov, D.A., 2018. Au-Cu-Ag mineralization in rodingite and nephritoids of the Agardag ultramafic massif (southern Tuva, Russia). Russian Geology and Geophysics 59, 238-256.

Pham, Q.D., 2015. Exploration report on no.3 and no.7 ore bodies of the Sin Quyen deposit, Lao Cai province [in Vietnamese]. Archival Magazine of National Geology Department of Vietnam.

Pieczonka, J., Piestrzyński, A., Le, P.K., Nguyen, C.D., Jodłowski, P., 2015. Rare Earth, Radioactive and selected elements in the iron oxide copper gold Sin Quyen deposit in North Vietnam. In: Viet-Pol 2015 second international conference on scientific research cooperation between Vietnam and Poland in Earth Sciences, 331-353. 
Pieczonka, J., Nguyen, C.D., Piestrzyński, A., Le, P.K., 2019. Timing of ore mineralization using minerals and U-Pb dating in IOCG Sin Quyen deposit, North Vietnam. Geological Quarterly (in Press).

Piestrzyński, A., 1989. Uranium and thorium in copper ore deposits on the Fore-Sudetic Monocline (SW Poland). Mieralogia Polonica 20 (1), 41-53.

Requia, K., Fontboté, L., 2000. The Salobo iron-oxide copper-gold deposit, Carajas, Northern Brazil, in Porter, T.M., ed., Hydrothermal iron oxide copper-gold and related deposits: A global perspective. PGC Publishing, Adelaide.

Requia, K., Stein, H., Fontboté, L., Chiaradia, M., 2003. Re-Os and Pb-Pb geochronology of the Archean Salobo iron oxide copper-gold deposit, Carajas mineral province, northern Brazil. Mineralium Deposita 38, 727-738.

Ta, V.D., 1975. Report of geological surveys and their results performed at the IOCG Sin Quyen deposit in Lao Cai, North Vietnam [in Vietnamese]. Main Department of Geology of Vietnam.

Zhao, X.F., Zhou, M.F., 2011. Fe-Cu deposits in the Kangdian region, SW China a Proterozoic IOCG (ironoxide-copper-gold) metallogenic province. Mineralium Deposita, 46 731-747.

Zhu, Z., 2016. Gold in iron oxide copper-gold deposits - A review. Ore Geology Review 72, 37-42. 


\section{Caption of Tables}

Table 1. Bulk chemical analyses of the samples from Sin Quyen deposit (ACME lab.)

Table 2. Correlation coefficients for ore and impurity elements in the samples from the Sin Quyen deposit

\section{Caption of Figures}

Fig.1. Localization of the Sin Quyen deposit on the geological sketch of the North Vietnam

Fig.2. Schematic illustration of the rock formation in the Sin Quyen region

Fig.3. Cross section of the ore body (photo 2015, looking NW direction)

Fig.4. Geological sketch of Sing Quyen deposit after Ta (1975)

Fig.5. View of weathered zone (photo, 2014)

Fig.6. Sampling localization

Fig.7a. BSE image showing position of electrum (Au) in relation to pyrite (py) and chalcopyrite (cpy)

Fig.7b. Intergrowth of allanite (all) with chalcopyrite (cpy). Reflected light

Fig.8. Plots of the relation between $\mathrm{Cu}$ and $\mathrm{Ag}(8 \mathrm{a}), \mathrm{Te}(8 \mathrm{~b}), \mathrm{Bi}(8 \mathrm{c}), \mathrm{Pb}(8 \mathrm{~d})$ and $\mathrm{Au}(8 \mathrm{e})$

Fig.9. Plot of the relation between $\mathrm{Au}$ and $\mathrm{Ag}$

Fig.10. Te-Bismuthinite (Te-Bmt) with chalcopyrite (Ccp) in reflected light

Fig.11. Intergrowth of uraninite (U) with magnetite (Mag), chalcopyrite (Ccp); allanite (Al) reflected light

Fig.12. The plot of relation between $\mathrm{Fe}$ and $\mathrm{Cu}$ concentration (the data were taken from the paper published by Ta, (1975))

Fig.13. Plots of relation between Co and Ni (13a), Co-Fe (13b) and Co-S (13c)

Fig.14. Plots of relation between U-Cu (14a), U-Pb (14b), U-Au (14c),U-Ag (14d), U- Bi (14e) and U-Te (14f)

Fig.15. Contour map of $\mathrm{Al}$ (15a), $\mathrm{Ca}(15 \mathrm{~b}), \mathrm{Ce}(15 \mathrm{c}), \mathrm{La}(15 \mathrm{~d}), \mathrm{Nd}(15 \mathrm{e})$ and $\mathrm{Ti}(15 \mathrm{f})$ in allanites

Fig.16. Plot of relation between $\mathrm{S}$ and $(\mathrm{Cu}+\mathrm{Fe})$. 
Table 1. Bulk chemical composition of the samples from Sin Quyen deposit (ACME lab.)

\begin{tabular}{|c|c|c|c|c|c|c|c|c|c|c|c|c|c|}
\hline & $\mathrm{Fe}$ & $\mathrm{Mn}$ & Co & $\mathrm{Ni}$ & $\mathrm{Au}$ & $\mathrm{Cu}$ & $\mathrm{Zn}$ & $\mathrm{Ag}$ & $\mathrm{Pb}$ & $\mathrm{Ga}$ & $\mathrm{Ge}$ & $S$ & Marks \\
\hline MDL & 0.01 & 1 & 0.1 & 0.1 & 0.2 & 0.01 & 0.1 & 2 & 0.01 & 0.1 & 0.1 & 0.02 & \\
\hline M1 & 25.52 & 274 & 328.7 & 240.3 & 502.6 & 11539 & 40.9 & 508 & 2.79 & 4 & 0.3 & 7.46 & Ep-Am rock, $\mathrm{Cu}-\mathrm{Fe}$ ore \\
\hline M2 & 7.74 & 308 & 47.6 & 21.4 & 511.1 & 32225 & 85.9 & 1188 & 3.79 & 5.5 & 0.4 & 2.38 & Ep-Am rock, $\mathrm{Cu}$ ore \\
\hline M5 & 28.45 & 528 & 82.3 & 22.7 & 343.5 & 29700 & 50.3 & 1075 & 17.53 & 17.8 & 0.8 & 1.14 & $\mathrm{Cu}-\mathrm{Fe}$ ore \\
\hline M6 & 13.36 & 499 & 57.2 & 27.4 & 237.5 & 26524 & 187.1 & 711 & 5.29 & 10.7 & 0.5 & 1.69 & $\mathrm{Bt}-\mathrm{Am}$ rock, $\mathrm{Cu}$ ore \\
\hline M7 & 31.35 & 305 & 71.8 & 37 & 59.3 & 4972 & 38.8 & 211 & 2.49 & 14.7 & 0.9 & 1.87 & massive $\mathrm{Fe}$ ore \\
\hline M8 & 24.28 & 1028 & 123 & 58.5 & 138 & 10914 & 137.8 & 506 & 3.7 & 22.1 & 0.7 & 2.58 & massive $\mathrm{Cu}-\mathrm{Fe}$ ore \\
\hline N4 & 13.21 & 583 & 57.3 & 23.1 & 1204.4 & 16976 & 173.5 & 1475 & 3.77 & 15.9 & 0.6 & 2.52 & Bt-Am rock, $\mathrm{Cu}$ ore \\
\hline N5 & 25.62 & 605 & 78.8 & 35.4 & 462.9 & 37861 & 118.2 & 1569 & 3.13 & 16.4 & 0.7 & 1.85 & Bt-Ep rock, $\mathrm{Cu}-\mathrm{Fe}$ ore \\
\hline N6 & 25.97 & 332 & 140.4 & 57.1 & 12687.5 & 74400 & 195.9 & 4159 & 33.92 & 13.8 & 0.6 & 2.66 & $\mathrm{Cu}-\mathrm{Fe}$ ore \\
\hline N7 & 7.66 & 414 & 44.8 & 23.9 & 727.7 & 17769 & 48.4 & 581 & 1.94 & 10.6 & 0.4 & 1.14 & $\mathrm{Cb}-\mathrm{Qtz}$ rock, $\mathrm{Cu}$ ore \\
\hline N8 & 11.13 & 399 & 67.2 & 40.9 & 161.9 & 20614 & 59.1 & 488 & 3.41 & 15 & 0.3 & 1.12 & Bt-Qtz-Amp rock $\mathrm{Cu}$ ore \\
\hline N9 & 6.43 & 627 & 16.8 & 9.7 & 88.9 & 1302 & 26.4 & 83 & 1.31 & 9.1 & 0.4 & 0.16 & Amphibolite \\
\hline N10 & 12.89 & 449 & 86.9 & 35.2 & 175.9 & 28309 & 96.4 & 952 & 2.8 & 23.1 & 0.3 & 1.26 & Amphibolite $\mathrm{Cu}$ ore \\
\hline N11 & 14.17 & 417 & 151.2 & 94.7 & 18503.7 & 82400 & 145.8 & 3050 & 24.27 & 11.7 & 0.3 & 2.95 & Massive $\mathrm{Cu}$ ore \\
\hline S5 & 21.02 & 272 & 60 & 24 & 681.2 & 26150 & 77.9 & 1090 & 6.09 & 9.6 & 0.5 & 1.84 & $\mathrm{Cu}-\mathrm{Fe}$ ore \\
\hline S6 & 21.53 & 244 & 139.9 & 51.7 & 2038.6 & 76083 & 109.9 & 2939 & 15.53 & 7.7 & 0.5 & 2.43 & Massive $\mathrm{Cu}-\mathrm{Fe}$ ore \\
\hline S7 & 2.08 & 156 & 3.6 & 4.9 & 10.4 & 394 & 12.6 & 30 & 0.89 & 6.2 & 0.1 & 0.07 & Carbonate-Quartz rock \\
\hline S8 & 26.06 & 334 & 65.2 & 28.6 & 750.1 & 19988 & 43.8 & 1844 & 2.14 & 18.6 & 0.7 & 1.75 & Massive $\mathrm{Cu}-\mathrm{Fe}$ ore \\
\hline S9 & 23.59 & 173 & 112.1 & 41 & 897.7 & 58040 & 104 & 2107 & 10.56 & 8.1 & 0.4 & 2.05 & $\mathrm{Cu}-\mathrm{Fe}$ ore \\
\hline $\mathrm{W}-15$ & 2.73 & 1085 & 12.2 & 7.3 & 3.1 & 186 & 32.5 & 8 & 1.76 & - & - & 0.1 & ore, open pit \\
\hline $\mathrm{W}-18$ & $>40$ & 319 & 99.2 & 41.4 & 2358.2 & $>10000$ & 88.3 & 1836 & 5.46 & - & - & 4.19 & massive ore \\
\hline $\mathrm{W}-25$ & 5.81 & 758 & 66.1 & 35.7 & 28.6 & 2935 & 34.1 & 139 & 7.61 & - & - & 1.7 & epid-amph rock \\
\hline $\mathrm{W}-31$ & 15.28 & 1479 & 29.1 & 9.4 & 16.9 & 3067 & 57.7 & 113 & 3.11 & - & - & 0.41 & skarn \\
\hline W-31a & 0.86 & 1264 & 2.3 & $<0.1$ & 1.6 & 39 & 33.3 & 14 & 3.7 & - & - & $<0.02$ & skarn with garnet \\
\hline Min & 0.86 & 114 & 2.3 & 4.9 & 1.6 & 39 & 9.1 & 8 & 0.89 & 4 & 0.1 & 0.06 & \\
\hline Max & 40 & 1479 & 328.7 & 240.3 & 18504 & 107900 & 196 & 4646 & 33.92 & 23.1 & 0.9 & 7.46 & \\
\hline Average & 17.2 & 480 & 86.6 & 46.5 & 1662.81 & 25670 & 80.6 & 1163 & 7.23 & 12.5 & 0.51 & 2.04 & \\
\hline Std. Dev & 10.4 & 324 & 68.2 & 51.7 & 4033.42 & 27465 & 53.45 & 1168 & 8.37 & 5.38 & 0.20 & 1.53 & \\
\hline W-36 & 35.0 & 236 & 183 & 91.6 & 6489.7 & $>10000$ & 580.1 & 30909 & 40.8 & - & - & 8.33 & $\mathrm{Cu}$-concentrate \\
\hline W-37 & $>40$ & 356 & 135.3 & 84.8 & 148.2 & 998 & 28 & 230 & 3.56 & - & - & 3.62 & Fe-concentrate \\
\hline $\mathrm{W}-39$ & 10.6 & 880 & 46.6 & 26.2 & 68.8 & 555 & 64.3 & 136 & 4.97 & - & - & 0.66 & Waste I \\
\hline
\end{tabular}




\begin{tabular}{|rrrrrrrrrrrrrrr} 
W-40 & 9.57 & 792 & 36.6 & 24.1 & 67.3 & 386 & 52.2 & 86 & 4.2 & - & - & 0.6 & Waste II & \\
W-44 & 12.17 & 711 & 30.9 & 20.1 & 166.7 & 335 & 42.3 & 86 & 5.31 & - & - & 0.77 & Waste out from tailing \\
\hline
\end{tabular}

Table 1. Continue

\begin{tabular}{|c|c|c|c|c|c|c|c|c|c|c|c|c|c|}
\hline $\begin{array}{l}\text { Elements } \\
\text { Units }\end{array}$ & $\begin{array}{l}\text { Sn } \\
\text { Ppm }\end{array}$ & $\begin{array}{l}\text { Te } \\
\text { ppm }\end{array}$ & $\begin{array}{l}\mathrm{Tl} \\
\mathrm{ppm}\end{array}$ & $\begin{array}{l}\mathrm{Bi} \\
\mathrm{ppm}\end{array}$ & $\begin{array}{l}\mathrm{Cd} \\
\mathrm{ppm}\end{array}$ & $\begin{array}{l}\mathrm{U} \\
\mathrm{ppm}\end{array}$ & $\begin{array}{l}\text { Th } \\
\text { ppm }\end{array}$ & $\begin{array}{l}\mathrm{Sr} \\
\mathrm{ppm}\end{array}$ & $\begin{array}{l}\mathrm{V} \\
\mathrm{ppm}\end{array}$ & $\begin{array}{l}\text { Cs } \\
\text { ppm }\end{array}$ & $\begin{array}{l}\mathrm{Cr} \\
\mathrm{ppm}\end{array}$ & $\begin{array}{l}\mathrm{Ti} \\
\%\end{array}$ & Marks \\
\hline MDL & 0.1 & 0.02 & 0.02 & 0.02 & 0.01 & 0.1 & 0.1 & 0.5 & 2 & 0.5 & 0.5 & 0.001 & \\
\hline M1 & 17.8 & 1.53 & 0.06 & 0.98 & 0.18 & 27.9 & 11.3 & 8.5 & 28 & 0.22 & 16 & 0.025 & Ep-Am rock, $\mathrm{Cu}-\mathrm{Fe}$ ore \\
\hline M2 & 25.3 & 1.5 & 0.06 & 1.47 & 0.39 & 91.9 & 30.5 & 48 & 50 & 0.38 & 8.1 & 0.078 & Ep-Am rock, $\mathrm{Cu}$ ore \\
\hline M3 & 67.3 & 1.52 & 0.02 & 1.23 & 0.1 & 83.5 & 28.6 & 20.9 & 44 & 0.8 & 18.8 & 0.072 & Ep-Am rock \\
\hline M4 & 19.6 & 3.53 & 0.21 & 2.85 & 0.45 & 28.4 & 7.6 & 11.3 & 90 & 3.34 & 19.3 & 0.083 & massive $\mathrm{Cu}-\mathrm{Fe}$ ore \\
\hline M5 & 14.8 & 1.71 & 0.57 & 1.22 & 0.23 & 219.7 & 12.6 & 102.1 & 104 & 6.72 & 20 & 0.141 & $\mathrm{Cu}-\mathrm{Fe}$ ore \\
\hline M6 & 22.7 & 1.06 & 0.34 & 0.5 & 0.7 & 36.1 & 12.6 & 19.3 & 50 & 3.14 & 26.8 & 0.098 & Bt-Am rock, $\mathrm{Cu}$ ore \\
\hline M7 & 21.1 & 1.15 & 0.03 & 0.28 & 0.12 & 5 & 3.7 & 12.3 & 37 & 0.41 & 5 & 0.017 & massive $\mathrm{Fe}$ ore \\
\hline M8 & 17.1 & 2.42 & 0.18 & 0.8 & 0.32 & 5.9 & 5.7 & 32.2 & 69 & 5.5 & 9.6 & 0.058 & massive $\mathrm{Cu}$-Fe ore \\
\hline N1 & 17.7 & 0.63 & 0.56 & 1 & 0.12 & 14.5 & 31.5 & 13.2 & 41 & 10.85 & 23.4 & 0.254 & Ep-Qtz-Pl rock \\
\hline $\mathrm{N} 2$ & 3.5 & 0.02 & 0.12 & 0.04 & 0.03 & 5.5 & 6.5 & 17 & 10 & 2.38 & 12.6 & 0.069 & Carbonate-Quartz rock \\
\hline N3 & 18.1 & 1.04 & 1.28 & 1.4 & 0.1 & 53.9 & 19.2 & 26.8 & 99 & 26.32 & 50.3 & 0.241 & skarn \\
\hline N4 & 27.1 & 1.99 & 0.87 & 1.16 & 1.46 & 33.7 & 23.4 & 9.7 & 65 & 16.93 & 36.7 & 0.148 & $\mathrm{Bt}-\mathrm{Am}$ rock, $\mathrm{Cu}$ ore \\
\hline N5 & 21.3 & 2.57 & 0.72 & 2.14 & 0.68 & 9.1 & 9.9 & 16.3 & 112 & 5.58 & 30 & 0.191 & Bt-Ep rock, $\mathrm{Cu}-\mathrm{Fe}$ ore \\
\hline N6 & 37.9 & 5.52 & 0.46 & 3.81 & 1.58 & 514.7 & 11.8 & 27.7 & 103 & 2.6 & 20 & 0.113 & $\mathrm{Cu}-\mathrm{Fe}$ ore \\
\hline N7 & 20.2 & 0.87 & 0.23 & 0.73 & 0.25 & 12.3 & 5.2 & 16.4 & 87 & 3.03 & 26.9 & 0.116 & $\mathrm{Cb}-\mathrm{Qtz}$ rock, $\mathrm{Cu}$ ore \\
\hline N8 & 8.8 & 0.62 & 0.62 & 0.36 & 0.26 & 60.6 & 7.4 & 6.6 & 67 & 8 & 117 & 0.167 & Bt-Qtz-Amp rock $\mathrm{Cu}$ ore \\
\hline N9 & 21.6 & 0.08 & 0.07 & 0.05 & 0.06 & 10.7 & 25.9 & 20.6 & 50 & 1.36 & 18.6 & 0.087 & Amphibolite \\
\hline N10 & 9.3 & 1.36 & 1.1 & 1.44 & 0.49 & 60.2 & 22.2 & 5.7 & 104 & 21.27 & 46.2 & 0.266 & Amphibolite $\mathrm{Cu}$ ore \\
\hline N11 & 20.8 & 4.44 & 0.42 & 4.64 & 1.02 & 335.6 & 10.1 & 17.8 & 78 & 2.27 & 32.5 & 0.061 & Massive $\mathrm{Cu}$ ore \\
\hline N12 & 5.6 & 1.14 & 0.88 & 0.84 & 0.15 & 41.6 & 14.3 & 8.3 & 87 & 14.41 & 63.8 & 0.266 & Ep-Am rock, $\mathrm{Cu}-\mathrm{Fe}$ ore \\
\hline S1 & 18.5 & 0.66 & 1.88 & 0.73 & 0.21 & 50.8 & 9.1 & 8.5 & 48 & 48.69 & 25.7 & 0.199 & Bt-Am schist \\
\hline S2 & 10.4 & 1.32 & 0.72 & 2.36 & 0.72 & 30.3 & 13 & 17.7 & 92 & 11.22 & 4 & 0.116 & $\mathrm{Cu}-\mathrm{Fe}$ ore \\
\hline S3 & 36.3 & 4.18 & 0.38 & 3.01 & 1.17 & 362.8 & 3 & 8.7 & 92 & 6.52 & 11.6 & 0.099 & Massive $\mathrm{Cu}-\mathrm{Fe}$ ore \\
\hline S4 & 24.1 & 7.13 & 0.08 & 4.67 & 0.7 & 319.2 & 13.1 & 25 & 81 & 1.01 & 1.9 & 0.045 & Massive $\mathrm{Cu}-\mathrm{Fe}$ ore \\
\hline S5 & 14 & 1.54 & 0.21 & 1.16 & 0.38 & 74.6 & 19.6 & 22.2 & 73 & 3.61 & 28.4 & 0.111 & $\mathrm{Cu}-\mathrm{Fe}$ ore \\
\hline S6 & 18.5 & 3.95 & 0.22 & 2.31 & 0.57 & 139 & 22.5 & 43.7 & 67 & 1.51 & 15.8 & 0.074 & Massive $\mathrm{Cu}-\mathrm{Fe}$ ore \\
\hline S7 & 1 & 0.03 & 0.06 & 0.06 & 0.01 & 3.3 & 12.8 & 6.7 & 15 & 0.63 & 6.9 & 0.015 & Carbonate-Quartz rock \\
\hline S8 & 10.7 & 1.41 & 0.53 & 2.34 & 0.11 & 37.4 & 42.4 & 16.2 & 138 & 5.71 & 25.9 & 0.17 & Massive $\mathrm{Cu}-\mathrm{Fe}$ ore \\
\hline S9 & 13.9 & 3.5 & 0.19 & 2.06 & 0.67 & 105 & 20.6 & 21.4 & 61 & 2.32 & 19.1 & 0.077 & $\mathrm{Cu}-\mathrm{Fe}$ ore \\
\hline $\mathrm{W}-15$ & - & 0.05 & - & 0.07 & 0.06 & 1.17 & 2.2 & 90.8 & 51 & - & - & 0.283 & ore, open pit \\
\hline $\mathrm{W}-18$ & - & 3.6 & - & 2.58 & 0.41 & 56.51 & 2.9 & 11.4 & 123 & - & - & 0.075 & massive ore \\
\hline $\mathrm{W}-25$ & - & 0.28 & - & 0.31 & 0.11 & 8.35 & 1.4 & 128 & 50 & - & - & 0.303 & epid-amph rock \\
\hline W-31 & - & 0.15 & - & 0.56 & 0.03 & 16.31 & 0.9 & 22.3 & 74 & - & - & 0.268 & skarn \\
\hline W-31a & - & $<0.02$ & - & 0.08 & 0.07 & 0.98 & 0.5 & 98.2 & $<2$ & - & - & 0.012 & skarn with garnet \\
\hline Min & 1 & 0.02 & 0.02 & 0.04 & 0.01 & 0.98 & 0.5 & 5.7 & 10 & 0.22 & 1.9 & 0.012 & \\
\hline Max & 67.3 & 7.13 & 1.88 & 4.67 & 1.58 & 514.7 & 42.4 & 128 & 138 & 48.69 & 117 & 0.303 & \\
\hline Average & 19.5 & 1.9 & 0.5 & 1.4 & 0.4 & 84.0 & 13.6 & 28.3 & 70.9 & 7.5 & 25.5 & 0.1 & \\
\hline Std Dev. & 12.4 & 1.7 & 0.4 & 1.3 & 0.4 & 122.6 & 10.2 & 30.3 & 30.2 & 10.3 & 22.5 & 0.1 & \\
\hline $\mathrm{W}-36$ & - & 4.91 & - & 5.39 & 3.31 & 20.56 & 2.2 & 52.1 & 62 & - & - & 0.06 & $\mathrm{Cu}$-concentrate \\
\hline
\end{tabular}




\begin{tabular}{|c|c|c|c|c|c|c|c|c|c|c|c|c|c|}
\hline W-37 & - & 0.64 & - & 1.28 & 0.1 & 22.7 & 2.9 & 13.1 & 219 & - & - & 0.125 & Fe-concentrate \\
\hline $\mathrm{W}-39$ & - & 1.04 & - & 1.74 & 0.14 & 32.56 & 12.2 & 51 & 89 & - & - & 0.245 & Waste I \\
\hline $\mathrm{W}-40$ & - & 0.86 & - & 1.32 & 0.14 & 30.64 & 8.7 & 45.1 & 83 & - & - & 0.256 & Waste II \\
\hline W-44 & - & 0.38 & - & 1.68 & 0.06 & 62.43 & 11.3 & 46 & 85 & - & - & 0.225 & Waste out from tailing \\
\hline
\end{tabular}

Table 1. Continue

\begin{tabular}{|c|c|c|c|c|c|c|c|c|c|c|c|c|c|c|}
\hline Elements & $\mathrm{Ba}$ & $\mathrm{Mg}$ & $\mathrm{Al}$ & $\mathrm{Na}$ & $\mathrm{K}$ & $\mathrm{Ca}$ & $\mathrm{Nb}$ & $\mathrm{Rb}$ & $\mathrm{Sc}$ & $\mathrm{Y}$ & LREE & HREE & TREE & Marks \\
\hline Units & ppm & $\%$ & $\%$ & $\%$ & $\%$ & $\%$ & ppm & ppm & ppm & ppm & ppm & ppm & ppm & \\
\hline MDL & 0.5 & 0.01 & 0.01 & 0 & 0.01 & 0.01 & 0.02 & 0.01 & 0.02 & 0.01 & 0.01 & 0.01 & 0.01 & \\
\hline M1 & 7 & 0.14 & 0.55 & 0.09 & 0.14 & 1.09 & 0.74 & 2.5 & 1.1 & 6.65 & 487 & 3.8 & 490 & Ep-Am rock, $\mathrm{Cu}-\mathrm{Fe}$ ore \\
\hline M2 & 6.7 & 0.34 & 0.95 & 0.12 & 0.19 & 2.16 & 1.5 & 4.9 & 3.2 & 20.41 & 2245 & 11.1 & 2256 & Ep-Am rock, $\mathrm{Cu}$ ore \\
\hline M3 & 4 & 0.03 & 0.59 & 0.01 & 0.02 & 4.12 & 2.49 & 3.8 & 1.8 & 81.39 & 1077 & 44.4 & 1122 & Ep-Am rock \\
\hline M4 & 13.4 & 0.25 & 0.56 & 0.06 & 0.25 & 0.59 & 2.55 & 24.5 & 2 & 9.49 & 704 & 4.7 & 709 & massive $\mathrm{Cu}-\mathrm{Fe}$ ore \\
\hline M5 & 170 & 1.71 & 2.03 & 0.02 & 2.3 & 2.58 & 2.03 & 115 & 3.3 & 17.2 & 1378 & 10.3 & 1388 & $\mathrm{Cu}-\mathrm{Fe}$ ore \\
\hline M6 & 130 & 0.53 & 1.63 & 0.08 & 1.15 & 1.4 & 1.27 & 56.8 & 2.6 & 9.12 & 622 & 5.1 & 627 & Bt-Am rock, $\mathrm{Cu}$ ore \\
\hline M7 & 10.9 & 0.14 & 0.68 & 0.11 & 0.13 & 0.92 & 0.33 & 4.3 & 1.4 & 4.24 & 145 & 2.3 & 148 & massive Fe ore \\
\hline M8 & 88.2 & 0.69 & 2.13 & 0.11 & 0.48 & 2.37 & 0.28 & 58.2 & 3.7 & 8.32 & 214 & 4.8 & 219 & massive $\mathrm{Cu}-\mathrm{Fe}$ ore \\
\hline N1 & 197 & 2.77 & 2.82 & 0.07 & 2.81 & 0.57 & 0.26 & 112 & 7.5 & 46.83 & 1466 & 25.9 & 1492 & Ep-Qtz-Pl rock \\
\hline $\mathrm{N} 2$ & 53.8 & 0.61 & 0.88 & 0.16 & 0.58 & 1.51 & 0.26 & 24.4 & 3.7 & 38.6 & 575 & 19.7 & 595 & Carbonate-Quartz rock \\
\hline N3 & 247 & 3.39 & 4.81 & 0.01 & 3.87 & 1.99 & 1.2 & 194.2 & 5.5 & 11.97 & 961 & 6.0 & 967 & skarn \\
\hline N4 & 128 & 0.59 & 2.16 & 0.17 & 1.11 & 1.29 & 1.14 & 107.7 & 6.2 & 14.87 & 672 & 7.8 & 680 & Bt-Am rock, $\mathrm{Cu}$ ore \\
\hline N5 & 155 & 1.52 & 2.28 & 0.03 & 2.21 & 1.04 & 1.47 & 114.4 & 11.9 & 13.33 & 832 & 7.2 & 840 & Bt-Ep rock, $\mathrm{Cu}$-Fe ore \\
\hline N6 & 80.6 & 0.48 & 1.08 & 0.04 & 0.62 & 1.02 & 0.72 & 39.1 & 2.4 & 17.85 & 626 & 10.2 & 636 & $\mathrm{Cu}-\mathrm{Fe}$ ore \\
\hline N7 & 112 & 0.91 & 1.99 & 0.2 & 0.76 & 1.46 & 0.37 & 37.8 & 3.4 & 9.57 & 184 & 4.8 & 189 & $\mathrm{Cb}-\mathrm{Qtz}$ rock, $\mathrm{Cu}$ ore \\
\hline N8 & 241 & 2.64 & 3.79 & 0.05 & 2.55 & 0.3 & 0.34 & 112 & 6.1 & 7.43 & 126 & 4.1 & 130 & $\mathrm{Bt}-\mathrm{Qtz}-\mathrm{Amp}$ rock $\mathrm{Cu}$ ore \\
\hline N9 & 21.3 & 1.26 & 2.16 & 0.34 & 0.26 & 2.82 & 0.27 & 10.3 & 4.1 & 13.91 & 173 & 6.8 & 179 & Amphibolite \\
\hline N10 & 284 & 5.43 & 5.9 & 0.01 & 4.11 & 0.32 & 1.11 & 178.5 & 5.7 & 8.2 & 154 & 4.5 & 159 & Amphibolite $\mathrm{Cu}$ ore \\
\hline N11 & 34.2 & 1.5 & 2.42 & 0.07 & 0.3 & 1.51 & 0.43 & 20.4 & 2.5 & 10.17 & 292 & 6.1 & 298 & Massive $\mathrm{Cu}$ ore \\
\hline N12 & 364 & 1.12 & 3.22 & 0.05 & 2.97 & 0.38 & 0.98 & 150 & 3.6 & 7.09 & 475 & 3.3 & 478 & Ep-Am rock, $\mathrm{Cu}-\mathrm{Fe}$ ore \\
\hline S1 & 159 & 3.35 & 3.57 & 0.03 & 3.3 & 0.46 & 0.58 & 294.2 & 2.4 & 4.99 & 421 & 2.5 & 424 & Bt-Am schist \\
\hline S2 & 104 & 2.57 & 2.19 & 0.03 & 2.84 & 0.49 & 1.73 & 170 & 2.2 & 10.4 & 656 & 4.9 & 661 & $\mathrm{Cu}-\mathrm{Fe}$ ore \\
\hline S3 & 57.6 & 0.5 & 1 & 0.04 & 0.79 & 0.6 & 1.55 & 59 & 1.6 & 11.42 & 177 & 6.4 & 184 & Massive $\mathrm{Cu}-\mathrm{Fe}$ ore \\
\hline S4 & 12.9 & 0.25 & 0.3 & 0.02 & 0.17 & 0.98 & 1.41 & 9.4 & 1.1 & 30.56 & 1694 & 15.8 & 1710 & Massive $\mathrm{Cu}-\mathrm{Fe}$ ore \\
\hline S5 & 74.8 & 0.45 & 1.14 & 0.1 & 0.72 & 0.76 & 1.95 & 45 & 3.5 & 9.55 & 1316 & 5.2 & 1321 & $\mathrm{Cu}-\mathrm{Fe}$ ore \\
\hline S6 & 32.4 & 0.46 & 0.93 & 0.11 & 0.43 & 1.56 & 1.5 & 24.7 & 2.8 & 17.35 & 2455 & 8.9 & 2464 & Massive $\mathrm{Cu}$-Fe ore \\
\hline S7 & 20 & 0.29 & 0.79 & 0.05 & 0.2 & 0.49 & 0.08 & 14.9 & 2.1 & 14.18 & 167 & 6.7 & 173 & Carbonate-Quartz rock \\
\hline S8 & 170 & 0.68 & 1.8 & 0.04 & 1.38 & 0.65 & 0.71 & 88.4 & 3.5 & 11.06 & 1364 & 5.6 & 1369 & Massive $\mathrm{Cu}-\mathrm{Fe}$ ore \\
\hline S9 & 48.3 & 0.34 & 0.81 & 0.08 & 0.51 & 0.64 & 1.59 & 30.8 & 1.8 & 10.18 & 1236 & 5.3 & 1241 & $\mathrm{Cu}-\mathrm{Fe}$ ore \\
\hline $\mathrm{W}-15$ & 154 & 1.03 & 8.52 & 4.22 & 1.34 & 6.72 & - & - & 9 & 17 & 51 & 7.3 & 59 & ore, open pit \\
\hline W-18 & 12.8 & 0.55 & 1.5 & 0.56 & 0.22 & 0.55 & - & - & 5 & 10 & 239 & 3.6 & 242 & massive ore \\
\hline $\mathrm{W}-25$ & 18.1 & 1.6 & 6.21 & 1.22 & 0.29 & 3.23 & - & - & 22 & 66 & 189 & 24.6 & 213 & epid-amph rock \\
\hline $\mathrm{W}-31$ & 31.4 & 3.61 & 4.58 & 1.03 & 1.07 & 6.04 & - & - & 16 & 52 & 122 & 20.7 & 142 & skarn \\
\hline $\mathrm{W}-31 \mathrm{a}$ & 6.2 & 0.26 & 1.95 & 0.02 & 0.02 & 29.1 & - & - & 1 & 11 & 19 & 2.4 & 22 & skarn with garnet \\
\hline Min & 4 & 0.03 & 0.3 & 0.01 & 0.02 & 0.3 & 0.08 & 2.5 & 1 & 4.24 & 19 & 2 & 22 & \\
\hline $\operatorname{Max}$ & 364 & 5.43 & 8.52 & 4.22 & 4.11 & 29.1 & 2.55 & 294.2 & 22 & 81.39 & 2455 & 44 & 2464 & \\
\hline Average & 95.6 & 1.2 & 2.3 & 0.3 & 1.2 & 2.4 & 1.1 & 72.7 & 4.6 & 18.6 & 692 & 9 & 701 & \\
\hline
\end{tabular}




\begin{tabular}{|lrrrrrrrrrrrrrr|} 
Std Dev. & 92.4 & 1.3 & 1.9 & 0.7 & 1.2 & 5.0 & 0.7 & 71.7 & 4.4 & 17.9 & 632 & 9 & 634 & \\
W-36 & 36.1 & 0.32 & 1.07 & 0.24 & 0.29 & 1.9 & - & - & 5 & 17 & 542 & 4.5 & 546 & Cu-concentrate \\
W-37 & 36.5 & 0.42 & 1.35 & 0.42 & 0.37 & 0.53 & - & - & 3 & 15 & 920 & 4.5 & 925 & Fe-concentrate \\
W-39 & 204 & 1.94 & 6.41 & 1.88 & 2.17 & 3 & - & - & 13 & 49 & 2550 & 18.9 & 2569 & Waste I \\
W-40 & 189 & 1.85 & 6.23 & 1.88 & 2.01 & 2.7 & - & - & 13 & 55 & 2559 & 15.8 & 2575 & Waste II \\
W-44 & 104 & 1.39 & 5.52 & 1.59 & 1.15 & 2.79 & - & - & 13 & 99 & 5450 & 21 & 5471 & Waste out from tailing \\
\hline
\end{tabular}


Table 2. Correlation coefficients for ore and impurity elements in the samples from the Sin Quyen deposit (39 samples)

\begin{tabular}{|c|c|c|c|c|c|c|c|c|c|c|c|c|c|c|c|c|c|c|c|c|c|}
\hline Elements & $\mathrm{Cu}$ & $\mathrm{Fe}$ & $\mathrm{Mn}$ & Co & $\mathrm{Ni}$ & $\mathrm{Au}$ & $\mathrm{Zn}$ & $\mathrm{Ag}$ & $\mathrm{Pb}$ & $\mathrm{Ga}$ & $\mathrm{Ge}$ & $\mathrm{s}$ & Sn & $\mathrm{Te}$ & $\mathrm{TI}$ & $\mathrm{Bi}$ & $\mathrm{Cd}$ & U & Th & V & REE \\
\hline $\mathrm{Cu}$ & 1 & & & & & & & & & & & & & & & & & & & & \\
\hline $\mathrm{Fe}$ & 0.53 & 1 & & & & & & & & & & & & & & & & & & & \\
\hline $\mathrm{Mn}$ & -0.44 & 0.1 & 1 & & & & & & & & & & & & & & & & & & \\
\hline Co & 0.46 & 0.59 & -0.08 & 1 & & & & & & & & & & & & & & & & & \\
\hline $\mathrm{Ni}$ & 0.15 & 0.31 & 0.05 & 0.9 & 1 & & & & & & & & & & & & & & & & \\
\hline $\mathrm{Au}$ & 0.73 & 0.17 & -0.12 & 0.33 & 0.21 & 1 & & & & & & & & & & & & & & & \\
\hline $\mathrm{Zn}$ & 0.67 & 0.39 & -0.09 & 0.26 & -0.04 & 0.49 & 1 & & & & & & & & & & & & & & \\
\hline $\mathrm{Ag}$ & 0.94 & 0.5 & -0.22 & 0.41 & 0.11 & 0.74 & 0.68 & 1 & & & & & & & & & & & & & \\
\hline $\mathrm{Pb}$ & 0.82 & 0.46 & 0.22 & 0.41 & 0.16 & 0.74 & 0.64 & 0.82 & 1 & & & & & & & & & & & & \\
\hline $\mathrm{Ga}$ & -0.08 & 0.28 & 0.59 & -0.17 & -0.32 & -0.05 & 0.23 & 0.03 & -0.03 & 1 & & & & & & & & & & & \\
\hline $\mathrm{Ge}$ & 0.11 & -0.18 & 0.33 & 0.21 & 0.05 & -0.07 & 0.24 & 0.21 & 0.2 & 0.49 & 1 & & & & & & & & & & \\
\hline $\mathrm{s}$ & 0.26 & 0.2 & 0.02 & 0.83 & 0.77 & 0.18 & 0.2 & 0.25 & 0.16 & -0.18 & 0.18 & 1 & & & & & & & & & \\
\hline Sn & 0.19 & 0.28 & 0.18 & 0.47 & 0.55 & 0.19 & 0.29 & 0.22 & 0.36 & -0.19 & 0.42 & 0.39 & 1 & & & & & & & & \\
\hline $\mathrm{Te}$ & 0.94 & 0.35 & -0.22 & 0.56 & 0.26 & 0.69 & 0.7 & 0.93 & 0.82 & 0.01 & 0.29 & 0.42 & 0.34 & 1 & & & & & & & \\
\hline $\mathrm{TI}$ & -0.18 & -0.32 & 0.35 & -0.22 & -0.22 & -0.09 & 0.13 & -0.08 & -0.13 & 0.61 & 0.07 & 0.14 & -0.18 & -0.18 & 1 & & & & & & \\
\hline $\mathrm{Bi}$ & 0.90 & 0.14 & -0.26 & 0.51 & 0.23 & 0.76 & 0.6 & 0.92 & 0.77 & 0.08 & 0.25 & 0.4 & 0.28 & 0.91 & 0.53 & 1 & & & & & \\
\hline $\mathrm{Cd}$ & 0.67 & -0.19 & -0.05 & 0.29 & 0.03 & 0.56 & 0.89 & 0.73 & 0.69 & 0.13 & 0.2 & 0.23 & 0.33 & 0.69 & 0.08 & 0.66 & 1 & & & & \\
\hline U & 0.78 & 0.41 & -0.23 & 0.35 & 0.11 & 0.78 & 0.62 & 0.81 & 0.97 & 0.03 & 0.14 & 0.09 & 0.31 & 0.78 & -0.04 & 0.75 & 0.69 & 1 & & & \\
\hline Th & 0.08 & 0.14 & -0.35 & -0.15 & -0.18 & -0.03 & -0.14 & 0.18 & -0.03 & -0.14 & -0.24 & -0.2 & -0.3 & 0.04 & -0.08 & 0.09 & -0.04 & -0.03 & 1 & & \\
\hline V & 0.39 & 0.56 & 0.2 & 0.08 & -0.17 & 0.21 & 0.34 & 0.47 & 0.3 & 0.69 & 0.53 & 0.1 & 0.03 & 0.43 & 0.46 & 0.56 & 0.33 & 0.33 & 0.03 & 1 & \\
\hline REE & 0.46 & 0.26 & -0.41 & 0.20 & 0.08 & 0.08 & 0.12 & 0.48 & 0.21 & -0.27 & 0.16 & 0.17 & 0.14 & 0.36 & -0.17 & 0.37 & 0.11 & 0.21 & 0.64 & 0.13 & 1 \\
\hline
\end{tabular}

